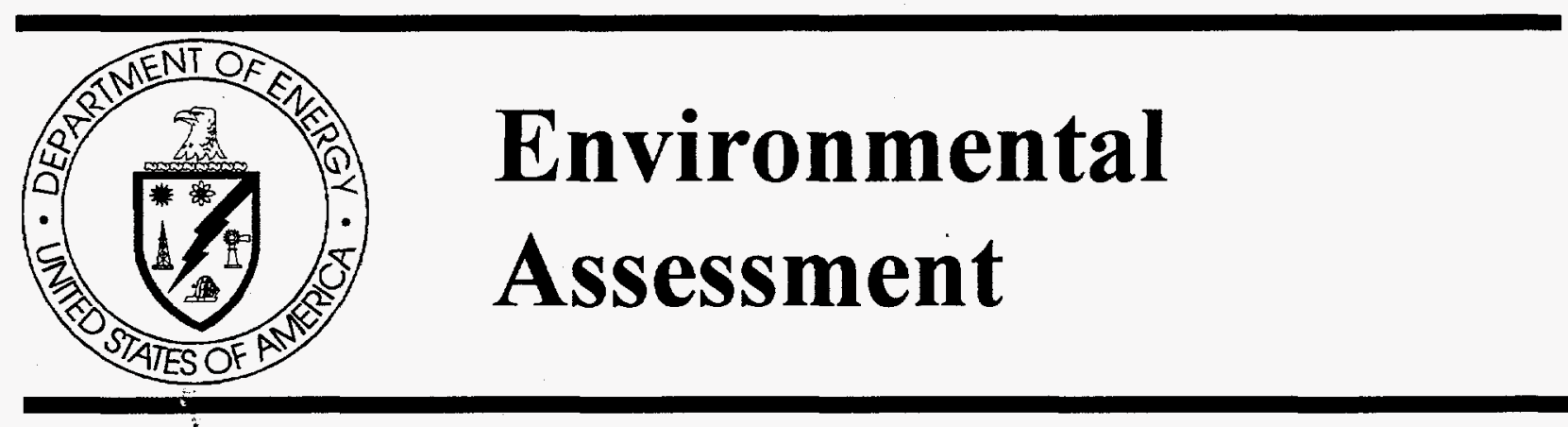

Kotzebue Wind Installation Project

Kotzebue, Alaska

U.S. Department of Energy

Golden Field Office

1617 Cole Boulevard

Golden, Colorado

May 1998

DISTRIBUTIN OF THIS DOCUMENT IS UNLMITED 


\section{DISCLAIMER}

This report was prepared as an account of work sponsored by an agency of the United States Government. Neither the United States Government nor any agency thereof, nor any of their employees, makes any warranty, express or implied, or assumes any legal liability or responsibility for the accuracy, completeness, or usefulness of any information, apparatus, product, or process disclosed, or represents that its use would not infringe privately owned rights. Reference herein to any specific commercial product, process, or service by trade name, trademark, manufacturer, or otherwise does not necessarily constitute or imply its endorsement, recommendation, or favoring by the United States Government or any agency thereof. The views and opinions of authors expressed herein do not necessarily state or reflect those of the United States Government or any agency thereof. 


\section{DISCLAIMER}

Portions of this document may be illegible in electronic image products. Images are produced from the best available original document. 


\section{Environmental Assessment}

Kotzebue Wind Installation Project

Kotzebue, Alaska

U.S. Department of Energy

Golden Field Office

1617 Cole Boulevard

Golden, Colorado

May 1998 


\title{
Finding of No Significant Impact
}

\author{
Environmental Assessment \\ Kotzebue Wind Installation Project \\ Kotzebue, Alaska
}

DOE/EA- 1245 


\section{FINDING OF NO SIGNIFICANT IMPACT \\ for \\ KOTZEBUE WIND INSTALLATION PROJECT \\ KOTZEBUE, ALASKA}

AGENCY: Department of Energy, Golden Field Office

ACTION: Finding of No Significant Impact

SUMMARY: The DOE is proposing to provide financial assistance to the Kotzebue Electric Association to expand its existing wind installation near Kotzebue, Alaska.

COPIES OF THE EA ARE AVAILABLE FROM:

Deborah Turner

DOE/GO NEPA Compliance Officer

U.S. Department of Energy

1617 Cole Boulevard

Golden, CO 80401

(303) $275-4746$

\section{FOR FURTHER INFORMATION ON THE DOE NEPA PROCESS CONTACT:}

Carol Borgstrom, Director

Office of NEPA Policy and Assistance

U.S. Department of Energy

1000 Independence Avenue, S.W.

Washington, D.C. 20585

(202) $586-4600$ or (800) $472-2756$

BACKGROUND: Like many rural Alaskan towns, Kotzebue uses diesel-powered generators to produce its electricity, the high cost of which is currently subsidized by the Alaskan State government. In an effort to provide a cost effective and clean source of electricity, reduce dependance on diesel fuel, and reduce air pollutants, the DOE is proposing to fund an experimental wind installation to test commercially available wind turbines under Arctic conditions. The results would provide valuable information to other Alaskan communities experiencing similar dependance on diesel-powered generators.

ENVIRONMENTAL IMPACTS: The EA for the proposed wind installation assessed environmental impacts to biological resources, land use, electromagnetic interference, coastal zone, 
air quality, cultural resources, and noise. The potential impacts from the wind installation could include some loss of wildlife habitat from constructing and operating the turbines, and increased bird mortality from collisions with turbine blades and towers. All construction activities would be conducted while the tundra is frozen to minimize impacts to the tundra and permafrost layer. The small amount of displaced habitat would pose no significant impact to wildlife because of the abundance of similar habitat in the surrounding area. While occasional bird strikes are possible, it is considered unlikely because the wind site is not a migratory staging area nor within a migratory corridor for waterfowl or shore birds. The wind installation does not pose any land use inconsistencies, nor does it have the potential to impact local radio transmission or airport navigational systems. The wind turbines would not produce any air emissions, and actually would reduce air emissions by displacing electricity produced from diesel generators. The existing site is located in an area devoid of cultural resources. Noise levels from wind turbine operation would be indiscernible from background noise in the area.

\section{ALTERNATIVES CONSIDERED:}

No Action: With the no action alternative Kotzebue Electric Association would continue to produce electricity from diesel generators and explore alternative energy technologies if and when funds are available. Because funding for wind energy projects outside the DOE are limited, the no action alternative would substantially delay, if not preclude, the opportunity to test a variety of wind turbines under Arctic conditions.

DETERMINATION: Based on the information in the Environmental Assessment, DOE determines that the Kotzebue Wind Installation Project does not constitute a major Federal action significantly affecting the quality of the human environment, within the meaning of the National Environmental Policy Act. Therefore, the preparation of an environmental impact statement is not required, and $\mathrm{DOE}$ is issuing this Finding of No Significant Impact.

Issued in Golden, Colorado, this 1998.

FrankM. Stewart

U.S. Department of Energy

Golden Field Office Manager 


\section{TABLE OF CONTENTS}

ACRONYMS AND ABBREVIATIONS

EXECUTIVE SUMMARY

ES-1

\section{CHAPTER 1}

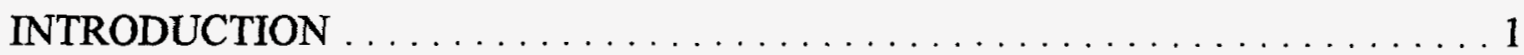

1.1 National Environmental Policy Act and Related Procedures $\ldots \ldots \ldots \ldots \ldots$

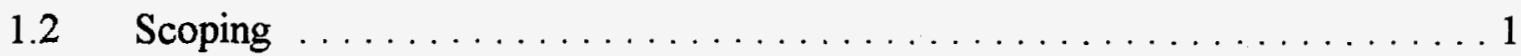

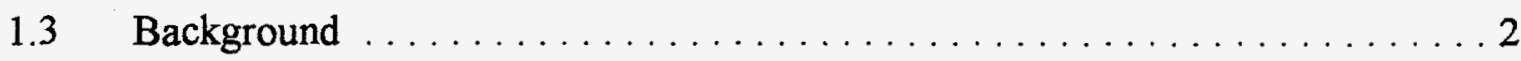

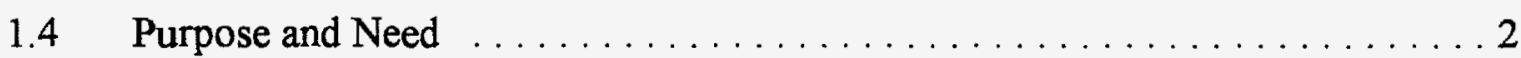

\section{CHAPTER 2}

PROPOSED ACTION AND ALTERNATIVES $\ldots \ldots \ldots \ldots \ldots \ldots \ldots \ldots$

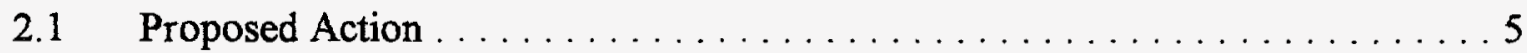

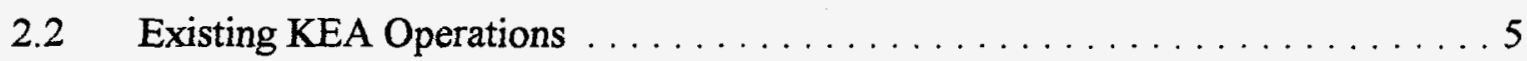

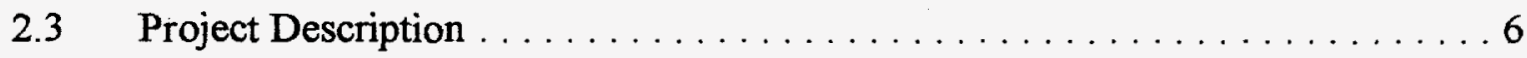

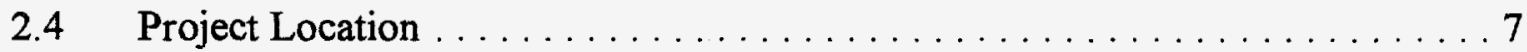

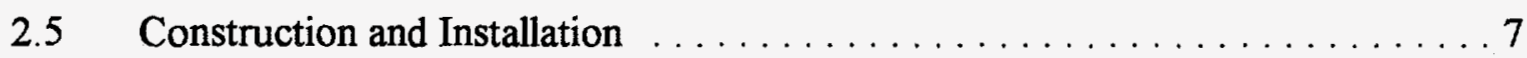

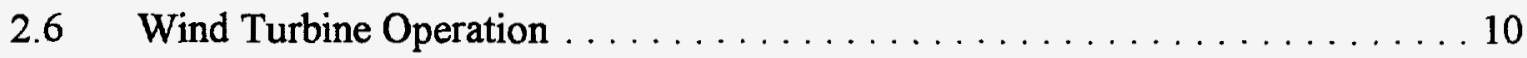

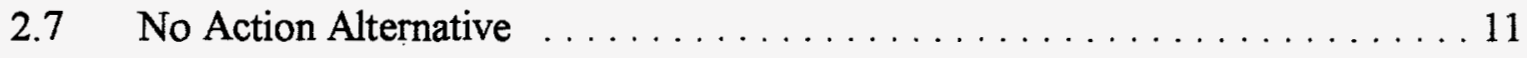

\section{CHAPTER 3}

AFFECTED ENVIRONMENT $\ldots \ldots \ldots \ldots \ldots \ldots \ldots \ldots \ldots \ldots \ldots \ldots$

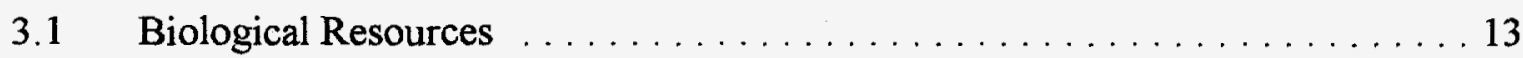

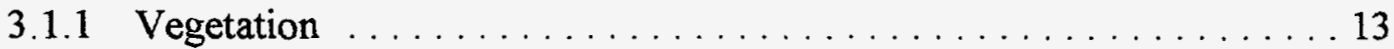

3.1 .2 Birds . . . . . . . . . . . . . . . . . . . . . . . . 13

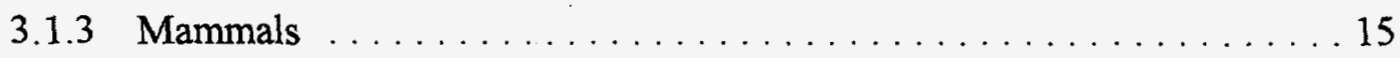

3.1.4 Threatened and Endangered Species $\ldots \ldots \ldots \ldots \ldots \ldots \ldots \ldots$

3.2 Land Use . . . . . . . . . . . . . . . . . . . . . . . . . . . . . . . . 16 


\section{TABLE OF CONTENTS (Continued)}

$3.3 \quad$ Coastal Zone . . . . . . . . . . . . . . . . . . . . . . . . . 17

3.4 Meteorology and Air Quality $\ldots \ldots \ldots \ldots \ldots \ldots \ldots \ldots \ldots \ldots \ldots \ldots \ldots \ldots \ldots \ldots \ldots$

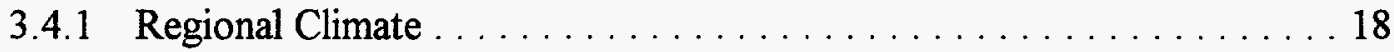

3.4 .2 Air Quality . . . . . . . . . . . . . . . . . . . 19

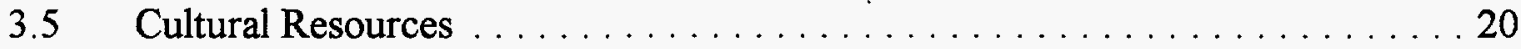

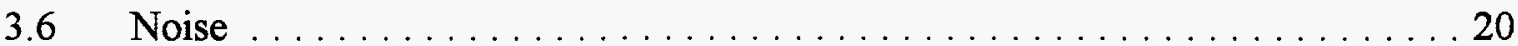

CHAPTER 4

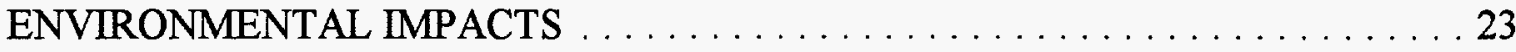

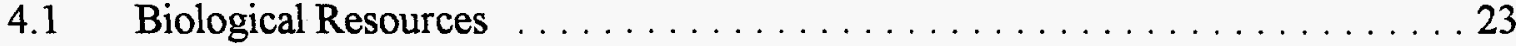

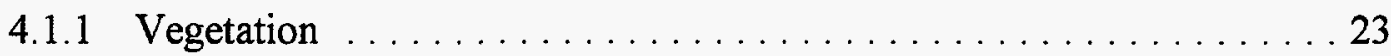

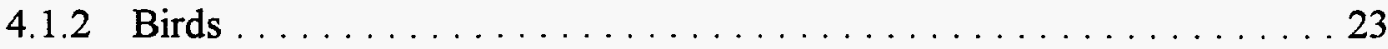

4.1 .3 Mammals .................................. 24

4.1.4 Threatened and Endangered Species $\ldots \ldots \ldots \ldots \ldots \ldots \ldots \ldots 24$

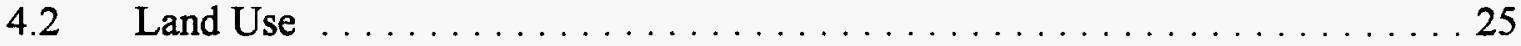

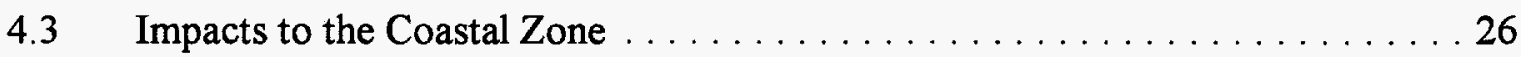

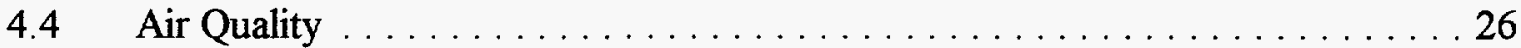

4.5 Cultural Resources/Human Environment . . . . . . . . . . . . . . . . . 27

4.5.1 Environmental Justice . . . . . . . . . . . . . . . . . . . . . . 27

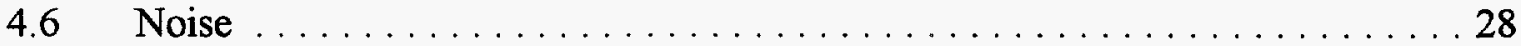

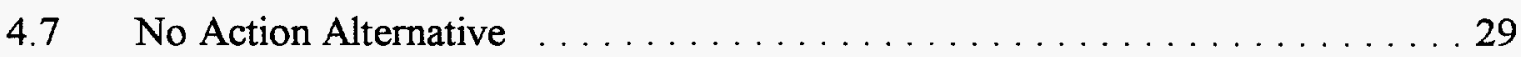

CHAPTER 5

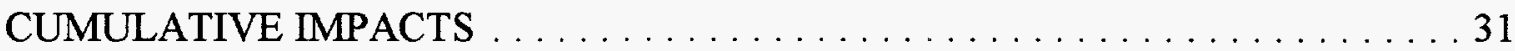

CHAPTER 6

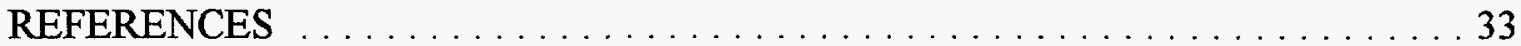

\section{CHAPTER 7}




\section{TABLE OF CONTENTS (Continued)}

\section{LIST OF FIGURES}

Figure

1 Kotzebue Wind Farm Project Regional Map $\ldots \ldots \ldots \ldots \ldots \ldots \ldots \ldots \ldots$

2 Kotzebue Wind Farm Project Vicinity Map and Plot Plan $\ldots \ldots \ldots \ldots \ldots \ldots$

\section{LIST OF TABLES}

Table

1 Operation-Related Noise Level Estimates 29

\section{LIST OF APPENDICES}

\section{APPENDIX A}

SCOPING LETTERS

APPENDIX B

NOTICE OF WETLANDS INVOLVEMENT

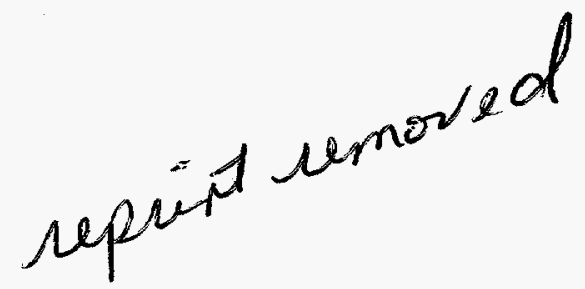

FOR THE KOZEBUE WIND FARM PROJECT

\section{APPENDIX C}

EA DISTRIBUTION LETTERS AND COMMENTS

APPENDIX D

LIST OF SPECIES IN KOTZEBUE REGION

APPENDIX E

NOISE AND ELECTROMAGNETIC INTERFERENCE ANALYSES 
This page left intentionally blank. 


\section{EXECUTIVE SUMMARY}

The U.S. Department of Energy's Golden Field Office is considering providing financial assistance to the Kotzebue Electric Association to expand its existing wind installation site near Kotzebue, Alaska. Like many rural Alaskan towns, Kotzebue uses diesel-powered generators to produce electricity, the high cost of which is currently subsidized by the Alaskan State government. In an effort to provide a cost effective and clean source of electricity, reduce dependance on diesel fuel, and reduce air pollutants, the DOE is proposing to partially fund the development of an experimental wind installation to test commercially available turbines under Arctic conditions. The results of the testing would provide valuable information to other Alaskan communities that rely solely on diesel-powered generators.

The proposed action consists of installing, operating, and maintaining up to 20 wind turbines and support equipment on an existing 148-acre site south of Kotzebue. Support equipment would consist of storage sheds or a larger storage structure to house electrical equipment needed to operate the turbines. Wind derived electricity would return to KEA via an existing distribution line at the project site.

The potential environmental impacts from the proposed expansion could include some loss of wildlife habitat from constructing and operating the turbines, and the potential for increased bird mortality from collisions with the turbine blades and towers. All construction activities would be conducted in winter months (November to April) to minimize impacts to the underlying tundra and permafrost layer. In addition, the DOE has evaluated potential adverse effects to land use, the coastal zone, air quality, cultural resources, noise, and electromagnetic interference, and found that the proposed action would not adversely affect these environmental categories. The beneficial impacts from the proposed project include a decreased dependance on diesel fuel and a subsequent reduction in air pollutants. 
This page left intentionally blank. 
ACMP Alaska Coastal Management Plan

ADOT Alaska Department of Transportation

AOC . Atlantic Orient Corporation

AWT Advanced Wind Turbine

CAA Clean Air Act

CEQ Council on Environmental Quality

DOE U.S. Department of Energy

$\mathrm{dB}$ decibel

dBA decibel, A-weighted

EA Environmental Assessment

EMI Electromagnetic Interference

EE DOE's Office of Energy Efficiency and Renewable Energy

F Fahrenheit

FAA Federal Aviation Administration

KEA Kotzebue Electric Association

KIC Kikiktagruk Inupiat Corporation

kWh Kilowatt hour

mph miles per hour

MW Megawatt

NAAQ National Ambient Air Quality

NAAQS National Ambient Air Quality Standard

NEPA National Environmental Policy Act 


\section{ACRONYMS AND ABBREVIATIONS (Continued)}

NOAA National Oceanic and Atmospheric Administration

NREL National Renewable Energy Laboratory

PCE Power Cost Equalization

USACE U.S. Army Corps of Engineers

USBIA U.S. Bureau of Indian Affairs

USFWS U.S. Fish and Wildlife Service 


\section{CHAPTER 1}

\section{INTRODUCTION}

\subsection{National Environmental Policy Act and Related Procedures}

This Environmental Assessment (EA) has been prepared in conformance with the National Environmental Policy Act (NEPA) of 1969, as amended (42 U.S.C. $\S \S 4321$, et seq.); the Council on Environmental Quality (CEQ) regulations for implementing the procedural provisions of NEPA (40 CFR Parts 1500-1508); the U.S. Department of Energy's (DOE) implementing procedures for compliance with NEPA (10 CFR Part 1021); Executive Order 11990, Protection of Wetlands; and the Department of Energy Compliance with Floodplain/Wetlands Environmental Review Requirements (10 CFR 1022). This assessment evaluates the potential individual and cumulative effects of the proposed Kotzebue Wind Turbine Installation Project on the physical, human, and natural environment. This document is intended to provide information to the U.S. Department of Energy and other public agency decision makers to assist in making informed decisions in connection with the proposed project. This document reflects DOE's independent evaluation and decision related to the potential environmental impacts associated with this proposed experimental wind installation in Kotzebue, Alaska.

\section{$1.2 \quad$ Scoping}

Federal, state, local, Inuit tribal, and other potentially interested organizations were sent scoping letters concerning the proposed action to assist the DOE in identifying potential issues. Appendix A contains copies of the scoping letters, the list of recipients, and the responses received. Additionally, a site visit was conducted during November, 1997, to view the proposed site and meet with Inuit tribal, state, and local organization representatives. The main areas of concern that have been expressed are potential impacts to avian (bird) species, potential impacts on migratory patterns of local animal populations, potential hazards in the local air space, visual aesthetics regarding the turbines, continued dependance on petroleum based fuels, and a reduction in air emissions from petroleum fuel combustion.

In accordance with EO 11990, Protection of Wetlands, and the Department of Energy Compliance with Floodplain/Wetlands Environmental Review Requirements, a Federal Register 
Notice was posted on February 17, 1998. This notice requested comments from interested parties and stated that the Wetland Assessment requirements would be incorporated into the EA associated with this project. A copy of the Federal Register notice is contained in Appendix B.

\subsection{Background}

Like many rural Alaskan towns, Kotzebue operates on electricity produced from dieselpowered generators. The high cost of diesel fuel is currently subsidized by the Alaskan State Government through the Power Cost Equalization Program (PCE) which helps reduce the cost of electricity in rural communities where diesel-fired generators provide a majority of electrical needs. Because of the potential loss of PCE funds, the cost of electricity in Kotzebue could increase by as much as 30 per cent for residential customers.

In an effort to find a cost-effective solution to increased electricity costs, Kotzebue Electric Association (KEA) and the State of Alaska have begun investigating the use of wind power to help supplant electricity derived from diesel generators. The knowledge acquired from this initiative would ideally be used to assist small Alaskan communities in operating their own wind installations. Through a combination of KEA and State funding, KEA was able to purchase and install three wind turbines in 1997. In order to increase both the number of turbines and the knowledge for operating wind and diesel power plants, KEA has approached DOE for additional funding.

\subsection{Purpose and Need}

The DOE Golden Field Office mission includes assisting organizations in advancing the development and commercialization of energy efficiency and renewable energy technologies such as wind-generated power. In an effort to provide a cost effective and clean source of electricity, reduce diesel fuel dependence, and reduce air emissions, the DOE proposes to partially fund the development of an experimental wind installation located in Kotzebue, Alaska. The proposed wind installation is intended to test commercially available turbines in extreme Arctic conditions in 
order to evaluate turbine performance and reliability under a wide range of temperatures, precipitation events, and strong Arctic winds. This information would be useful in applying wind power technology to other Alaskan villages experiencing similar dependance on diesel-powered generators. 
This page left intentionally blank. 


\section{CHAPTER 2}

\section{PROPOSED ACTION AND ALTERNATIVES}

\subsection{Proposed Action}

The Department of Energy's Golden Field Office is considering providing financial assistance to the Kotzebue Electric Association (KEA) to expand its existing wind installation site near Kotzebue, Alaska, north of the Arctic Circle. The proposed action would reduce consumption of petroleum-based fuels by harnessing wind energy as an additional source of electrical power production. The existing diesel generators would be kept on line for supplemental electrical power as needed.

\subsection{Existing KEA Operations}

KEA is a nonprofit rural electric system cooperative that serves about 1,200 retail customers in Kotzebue, Alaska. Both the power plant and administrative offices are centrally located in Kotzebue. Like many rural Alaskan towns, Kotzebue operates solely on electricity

produced from its diesel-powered generators. KEA currently maintains six generators which are capable of producing 11.18 megawatts (MW) of electricity. KEA's operating load ranges from a low of 1.7 MW to a high of 3.7 MW, with an average of $2.5 \mathrm{MW}$. The average cost to consumers is $\$ 19.96$ cents per kilowatt hour $(\mathrm{kWh})$.

Under normal conditions KEA operates only one or two of its generators; the remaining generators provide redundancy. During periods of low electrical load - as in the summer months and most winter nights - one generator runs continuously while the second is used as needed. Under heavy loads, KEA operates two generators simultaneously. Data from the last five years indicates that KEA consumes an average of 1,392,850 gallons of diesel fuel per year with an average efficiency of approximately $14 \mathrm{kWh}$ per gallon of fuel. KEA's power output for 1997 was approximately 20 million $\mathrm{kWh}$.

Under a separate project funded by KEA and Alaska's Division of Energy, KEA installed three Atlantic Orient Corporation (AOC) turbines in the Spring of 1997. As the wind turbine 
system is relatively new, KEA's focus has been on collecting performance data and debugging the electrical equipment and mechanical systems.

\subsection{Project Description}

The proposed project would consist of installing, operating, and maintaining up to 20 wind turbines and ancillary equipment on an existing 148-acre wind installation site near Kotzebue, Alaska, herein referred to as the project site.

The goal of the proposed project is to provide between one and two MW of wind derived electricity to the KEA power grid. The proposed turbines would most likely consist of two and three bladed units. Specific candidate turbines might include the AOC 15/50, the Advanced Wind Turbine (AWT) 27 or 26, and the New World Polar 100. The power ratings for the three turbines are $50 \mathrm{~kW}, 275 \mathrm{~kW}$, and $100 \mathrm{~kW}$, respectively. Total wind turbine height varies for each model but ranges from approximately 107 to 186 feet. While the three turbines vary in size, power rating, and spacing requirements, they share similarities in installation and operation procedures.

Support and ancillary equipment would consist of either insulated storage sheds (control sheds) or a larger storage structure to house breaker panels, tools, and other equipment required to operate and maintain the wind turbines. The structures would be skid or piling mounted to preclude adverse effects to the underlying tundra. If control sheds are used they would consist of preassembled shipping containers measuring approximately 8 feet $(\mathrm{ft}$ ) wide $\times 8 \mathrm{ft}$ high $\times 20 \mathrm{ft}$ long. Each shed would house equipment to control three to four turbines. If a pile mounted building is used it could potentially be $28 \mathrm{ft}$ wide $\mathrm{x} 40 \mathrm{ft}$ long to house the majority of the equipment.

The wind generated power would be fed into the KEA grid via an existing 7200 volt (V) distribution line installed in March of 1996 to support the existing wind turbines. This line has the capacity to carry $4 \mathrm{MW}$ of electricity and would not require upgrading as a result of the proposed project. 


\subsection{Project Location}

The 148-acre project site is located approximately 4.5 miles south of Kotzebue, Alaska. KEA leases the site from the Kikiktagruk Inupiat Corporation (KIC), the local Inupiat Eskimo corporation that owns the land. The site is rectangular, measuring approximately $1800 \mathrm{ft}$ by 3600 $\mathrm{ft}$. (Figures 1 and 2). The project site is roughly 0.5 miles from the coast and approximately 50 feet above sea level. Access to areas south of Kotzebue is via a dirt road that leads from Kotzebue to a U.S. Air Force White Alice Communication installation, then continues south along the coast. Under a separate but related action, KEA applied for, and received, U.S. Army Corps of Engineers' (USACE) approval for an access road that would extend from the Air Force property to the project site (USACE, 1997a). The road would be 0.7 mile long by approximately $18 \mathrm{ft}$ wide and would consist of a geofabric underlayment placed over the tundra followed by 6000 cubic yards $\left(\mathrm{yds}^{3}\right)$ of silty sand and $2000 \mathrm{yds}^{3}$ of coarse gravel for the road bed.

\subsection{Construction and Installation}

KEA would procure the turbines in two phases between 1998 and 2000 . In 1998, seven additional AOC Model 15/50 turbines would be purchased and installed. After a period of operating those units, it is anticipated that additional turbines would be chosen based on turbine availability and experiences from the first phase of operation.

Wind turbine construction and installation would occur in stages and consist of installing pilings, and assembling and raising the turbines and towers. The tower foundations would consist of freezeback pilings placed in the permafrost which serve to anchor the towers to the ground. Freezeback pilings are a standard construction component in Alaska and are specially engineered to prevent significant temperature changes in the permafrost, thus preventing heaving. Piling excavation would consist of augering three 16- to 22-inch diameter holes per tower, approximately 25 to $30 \mathrm{ft}$ deep. After foundation preparation, the towers would be raised and the turbines and blades installed.

Construction is expected to take place in the winter months (November to April) to minimize impacts to the tundra and permafrost layer. Heavy equipment needed to complete this project would most likely consist of equipment for transporting the hardware to the site, boring 


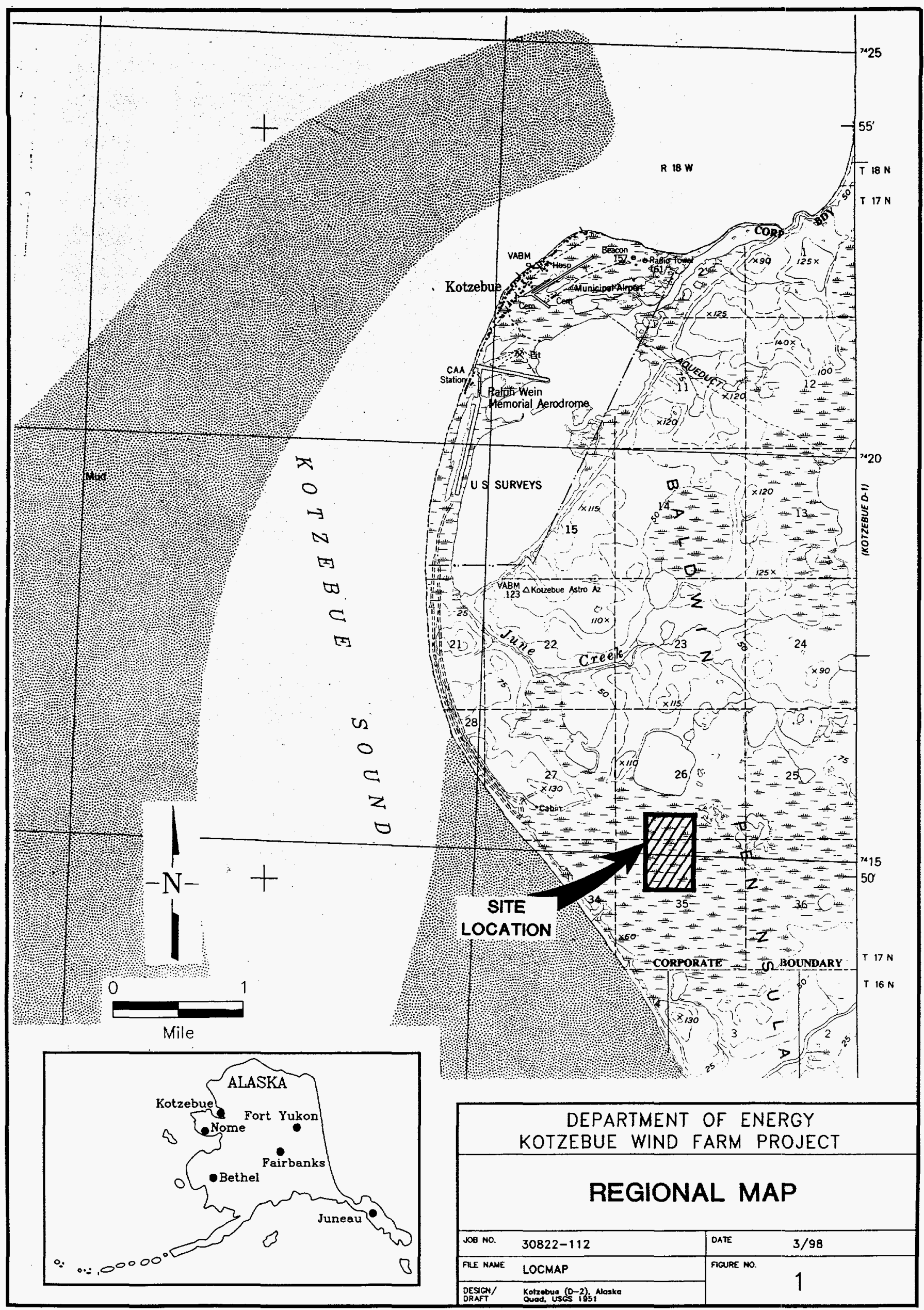




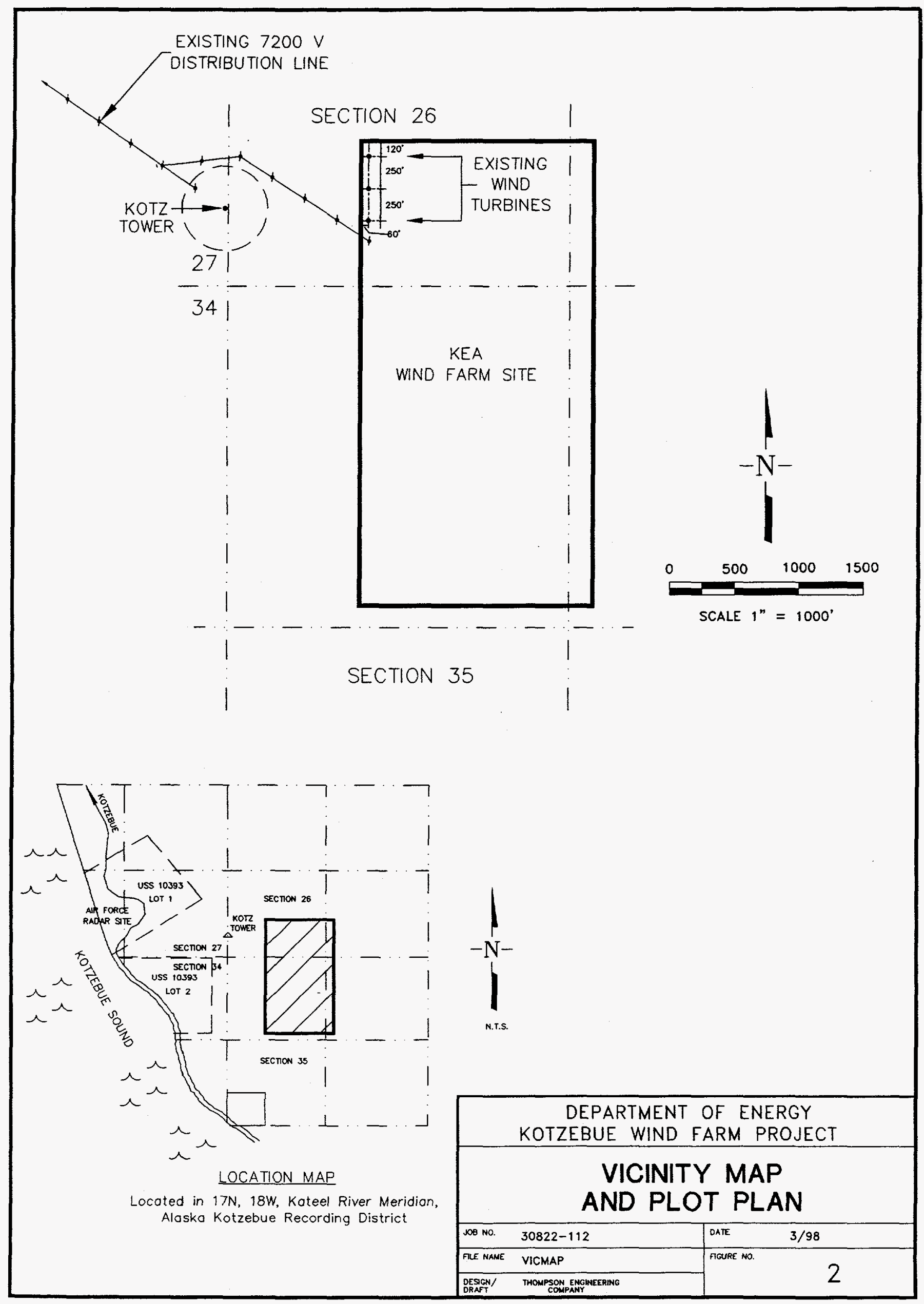


the piling holes, and raising the tower and turbine assembly. The equipment would be operated intermittently as the schedule for installing the turbines spans two years. Construction experience from installing the three existing turbines indicates that it takes approximately one week to install one AOC turbine. Because of their larger size, it is expected that installing the AWT and New Polar units may take longer.

In addition to existing KEA employees, it is anticipated that contract laborers may be needed for wind turbine construction and installation. These laborers would be supplied by the local labor force and would not require relocating workers for this project. Based on experience from installing the AOC turbines, it is reasonable to expect that a manufacturer's representative would assist with initial installation and troubleshooting, particularly for the AWT and New World Polar turbines. This is not expected to last for more than a couple of weeks and would not require permanent relocation for that individual.

\subsection{Wind Turbine Operation}

Wind turbines, like gas and hydroelectric turbines, are designed to convert rotational energy into electricity through the use of a generator. Some of the design features for the selected turbines include: wood-epoxy blades, redundant brakes, the ability to rotate with the prevailing wind direction, and a design life of 30 years. The speed at which these turbines start spinning (cut-in speed) is approximately 9 to 11 miles per hour ( $\mathrm{mph}$ ), while the maximum speed at which they shut-down (cut-out speed) is between 50 and $70 \mathrm{mph}$ depending on the specific model. All the turbines are designed to withstand a maximum wind speed of $133 \mathrm{mph}$. The tower assembly may consist of a solid tubular construction, or latticed. Electricity from the wind turbines is directed via insulated surface cable to the control sheds, the distribution line, and to the KEA grid. The effective coordination of diesel and wind power is a complex process. One goal of this project is to gain enough operational knowledge to effectively manage the energy contributions from the wind turbines and the diesel generators.

Routine maintenance on the wind turbine equipment would be based on manufacturerspecific recommendations, but is anticipated to occur every three to six months or after severe events (e.g. extreme wind). Maintenance would essentially consist of inspecting the turbines and 
towers to ensure the integrity of the components and fasteners, and changing out gearbox oil. The frequency of oil changes is dependent on the type of oil. Conventional oils require changing approximately once per year, while synthetic oils need changing less frequently (every 5 years). The AOC 15/50 gearbox contains approximately 9 gallons of oil, while the AWT-26 gearbox holds approximately 15 gallons (AWT, 1997). KEA personnel would collect the oil in approved containers and dispose of it at KEA in an existing waste oil burner.

\subsection{No Action Alternative}

Under the no action alternative, KEA would continue to produce electricity from diesel generators and explore alternative energy technologies if and when the funds are available. Current funding for wind energy projects outside of the DOE is limited and, consequently, projects of this magnitude are often times impossible, especially in remote regions. The no action alternative would substantially delay, if not preclude, both the opportunity to test a variety of wind turbines in Arctic conditions and gain experience in managing diesel/wind hybrid facilities. 
This page left intentionally blank. 


\section{CHAPTER 3}

\section{AFFECTED ENVIRONMENT}

\subsection{Biological Resources}

In the fall of 1997, a biological assessment was conducted to characetrize the vegetation, birds, and mammals at the proposed project site, and to evaluate potential impacts to these resources from expanding the wind installation. The assessment and results are contained in the report, "Biological Assessment of the Kotzebue Wind Farm Site, Kotzebue, Alaska" (D\&M, 1997). The following is a summary of the existing flora and fauna based on personal observation and consultation with both the U.S. Fish and Wildlife Service and the Alaska Department of Fish and Game.

Kotzebue is located on the very north end of the Baldwin Peninsula, approximately 30 miles north of the Arctic Circle. Kotzebue is within the Northwest Region of Alaska and is characterized by continuous permafrost, numerous lakes and ponds, treeless coastal tundra, and wet and moist tundra. The low-lying terrain and shallow permafrost result in poor drainage of surface runoff and produce extensive areas of wetland habitat.

\subsubsection{Vegetation}

The site is in an area comprised mostly of moist tundra and wet tundra. Moist tundra is common in foothills and better drained sites, and covers extensive areas throughout the region. This plant community is characterized by diverse plant species and varies from an almost continuous and uniformly developed tussock tundra to dense stands of dwarf shrubs. Wet tundra communities occupy much of the lowland areas, with vegetation usually dominated by grasses and sedges. Wet tundra communities are often interspersed with small lakes and ponds.

\subsubsection{Birds}

The varied habitats in Northwest Region of Alaska support an abundance of bird life, including several Asiatic species that frequent the area. A site reconnaissance to support the biological assessment was conducted in October, 1997, after most of the migrant birds had left the area, and only two resident bird species were observed in vicinity of the site. 
Waterfowl use of the area surrounding the site would be expected to be primarily for nesting in the wetlands and small lakes in the area (D\&M, 1997). However, the lack of open water habitat such as lakes or ponds at the project site is likely a limiting factor as far as nesting in the immediate area. Small lakes and ponds are found approximately 0.25 miles to the north and east of the site. The site is not within a major migration corridor and there are no major waterfowl staging areas in this portion of the Baldwin Peninsula. Most migratory bird movements are to the east in the Kobuk River delta within the Selewik National Wildlife Refuge and farther offshore for spring movements of seaducks and Brant.

Common shorebirds in the Kotzebue area include over 30 species of migrants and breeders. No major shorebird staging areas or migration corridors have been documented near the project site. The nearest shorebird staging area is the Kobuk River delta, approximately 20 miles to the north. During spring migration, much of the shoreline habitat near the project site is still iced-in and little habitat is available. Fall migration is much more protracted and shorebirds have a wider variety of habitat to use and are not as concentrated.

Raptors are generally uncommon in the Kotzebue area. The only common species is the Northern Harrier, a summer resident which breeds in the area. Other species which could potentially be seen during spring and fall migration in the area include Rough-legged Hawks, Golden Eagles, Merlins, and Gyrfalcons. Snowy Owls are uncommon winter residents in this region, but migrate in higher numbers during winters when populations of their main prey species (lemmings) undergo population crashes.

Common passerines (perching birds) in the vicinity of the project site include both resident species and species which migrate to the northwest region to breed during the short Arctic summer. Resident passerine species are few and include only Common and Hoary Redpolls. Summer breeders include Wilson's Warbler, Yellow Warbler, and Northern Waterthrush. However, most of these species nest in habitats with a higher shrub component.

The Willow Ptarmigan is one of the common resident species in the area. Numerous ptarmigan tracks were observed in the low shrub-willow communities just west of the project site 
during the site reconnaissance. These birds are residents of the area but may undergo shifts in distribution depending on the season. The Common Raven is also a resident of the area and a nest was documented on an old building adjacent to the project site. Bank Swallows are also common, especially along the coast. Glaucous Gulls, Arctic Terns, and Long-tailed and Parasitic Jaegers would also be expected to occur near the project site. The Sandhill Crane is also a regular breeder and migrant in the project area.

\subsubsection{Mammals}

The Northwest Alaska Region supports approximately 20 species of terrestrial mammals and many of these are found on the Baldwin Peninsula. Small mammal species which are most likely to occur in the immediate vicinity of the project site include masked and tundra shrews, snowshoe hare, tundra redbacked vole, brown and green-collared lemmings, meadow vole, Alaska vole, and tundra voles (D\&M, 1997). Least and short-tailed weasels are also found in the general area.

Large mammals include brown bear, Arctic fox, red fox, coyote, wolf, muskox, and caribou, and occasional feral reindeer. Fox tracks were observed at the site during the reconnaissance. These predator/scavengers are common in the general vicinity of the site throughout the year. Coyotes and wolves would be expected to be less common in the area.

The Baldwin Peninsula is within the winter range of the Western Arctic Caribou Herd which currently numbers approximately 463,000 animals. Animals from this herd are known to occur in the vicinity of the project site for short periods of time during the spring and fall as caribou are migrating and a few animals spend the winter on the Baldwin Peninsula. Most caribou range considerable distances and use large geographic areas to forage during the winter months.

Muskox from herds on the Seward Peninsula to the south are occasionally observed in the vicinity of the project site. 


\subsubsection{Threatened and Endangered Species}

There are no Northwest Alaska Region plant species listed under the Endangered Species Act of 1972. However, there is one species of oxytrope which occurs in the general vicinity of Kotzebue that is considered a species of interest. This small legume has been documented along the sides of gravel roads and building pads in the general vicinity of the site. The habitat of this species, well-drained gravel or stony soil, does not naturally occur at the site since most of the site is wet tundra.

The Baldwin Peninsula is within the range of the Arctic Peregrine Falcon which was delisted in October 1994. This falcon does not nest in this region but can pass through the area during spring and fall migration.

The coastal areas around Kotzebue Sound and the Chukchi Sea are within the range of the Spectacled Eider and Steller's Eider, both listed as threatened species under the ESA. The Steller's Eider was listed on June 11, 1997. These birds are not known to nest in the Kotzebue region (only known to nest near Barrow, approximately 330 miles north) and would be primarily migrants. Migratory movement of these seaducks is typically offshore, but they may migrate over land or use coastal habitats to feed or rest. The North American population of Spectacled Eiders has declined over 90 percent in recent years.

There are no threatened or endangered terrestrial mammals in this region.

\subsection{Land Use}

KIC owns approximately 8,790 acres of land in the Kotzebue area. The 148-acre project site leased to KEA represents approximately $1.7 \%$ of the proximate KIC land (Reeve 1997). While there are no formal land use guidance plans in existence, consultation with KIC has indicated that the wind turbine project does not conflict with any other intended land uses for this area. Using the site for wind energy was described by KIC as " the highest and best use of the land" (D\&M, 1997). There are some existing facilities and structures that are worthy of discussion as they are either in the vicinity of the wind installation site or could be potentially impacted by wind turbine operation. 
The Ralph Wien Memorial Airport is located immediately south of Kotzebue and approximately 4.5 miles northwest of the project site. The airport occupies approximately 1,805 acres of State-owned land, most of which is the Kotzebue Lagoon. The State is currently updating the airport's Master Plan as not all aviation operations are fully compliant with Federal Aviation Administration (FAA) regulations. In updating the plan, the State is evaluating alternatives for modifying and redeveloping portions of the airport. The preferred alternative consists of modifications and upgrades to the airport at its existing location. However, one alternative is to relocate the airport just south and east of the project site. According to the Alaska Department of Transportation (ADOT), implementing this alternative is considered extremely unlikely because of the high cost associated with building a new facility and developing infrastructure needed to access this location (ADOT, 1997).

KOTZ-AM radio in Kotzebue operates a 700 kilohertz radio tower that is approximately 320 feet tall and located approximately 1000 feet to the west of the project site. Less than a mile to the west of the project site is the abandoned U.S. Air Force White Alice Communications station which was used to relay communications to remote military installations and villages. Also, in 1996 Kotzebue opened a new solid waste landfill approximately 2 miles northwest of the project site.

\subsection{Coastal Zone}

The Alaska Coastal Management Program (ACMP) is administered by the Division of Governmental Coordination to ensure the protection and enhancement of habitats and resources in its coastal areas. The ACMP identifies several categories of habitat including estuaries, wetlands and tideflats, and rivers, streams, and lakes. Resources include air, land, and water, as well as historic, prehistoric, and archaeological resources.

The USACE 404 permit process triggers a review for consistency with State and Federal regulations governing Alaska's coastal zones. The USACE has determined that the wind installation expansion is not subject to the 404 process (USACE, 1997b). Additionally, the access road permit application was reviewed by the Alaska Departments of Natural Resources, Environmental Conservation, and Fish and Game, and the Northwest Arctic Borough Coastal 
District. These agencies determined that the proposed access road is consistent with the ACMP provided that modifications concerning adequate drainage, minimizing erosion and loss to wetlands, and fill requirements would be implemented (DGC 1997).

\subsection{Meteorology and Air Quality}

\subsubsection{Regional Climate}

Northwest Alaska is characterized by long cold winters and short cool summers.

Kotzebue is bounded on the north and west by the Kotzebue Sound and east by the Hotham Inlet, known locally as Kobuk Lake. These bodies of water produce a maritime type climate when the water is ice-free (roughly late May to late October). During this period, cloudy skies prevail, fog occurs, daily temperatures are relatively uniform, relative humidity is high, and westerly winds predominate. When the water surrounding the peninsula is frozen, the climate approaches that of a continental type, exhibiting large daily temperature ranges, low humidity, and moderate rainfall. The continental climate becomes more pronounced as the ice cover advances across the sound to the Arctic Ocean.

Local topography is nearly uniform with a general low relief. There are no significant terrain barriers in the immediate area to impede surface air flow or produce pronounced local variation in temperature and precipitation. The mountainous Seward Peninsula to the south, however, does deflect some low pressure systems which originate in or beyond the Bering Sea area and move toward the Kotzebue region.

Kotzebue's mean annual precipitation is 9.20 inches which includes an average of 47.5 inches of snowfall. Average temperatures range from $-9^{\circ}$ Fahrenheit $(\mathrm{F})$ in January to $59^{\circ} \mathrm{F}$ in July, with extreme temperatures ranging from $-52^{\circ} \mathrm{F}$ to $85^{\circ} \mathrm{F}$. Wind direction and speed change throughout the calendar year. From December to March, the prevailing wind direction is easterly; from May to August the prevailing direction is westerly. The average annual wind speed is 13 miles per hour (mph) with an average wind speed range from $11.0 \mathrm{mph}$ in May to $14.6 \mathrm{mph}$ in November. Peak gusts have reached speeds of $72 \mathrm{mph}$ (NOAA, 1994). 
The available wind power for a given area is a function of average wind speed and is measured in watts per square meter. According to the "Wind Energy Resource Atlas of the United States," Kotzebue is classified as a Class 6 overall wind regime and a Class 7 winter regime (KEA, 1997).

\subsubsection{Air Quality}

In 1970, Congress passed the Clean Air Act (CAA) which established air quality programs to regulate air emissions from stationary, mobile, and other sources which pose a risk to human health and the environment. The CAA gives the Environmental Protection Agency authority to establish National Ambient Air Quality Standard (NAAQS) for pollutants such as sulphur dioxide, carbon monoxide, nitrogen dioxides, ozone, as well as others. Ambient air quality is primarily a result of the type and amount of pollutants emitted into the atmosphere. Areas of the country that have attained the NAAQ standards for a particular pollutant are considered attainment areas, while those areas that exceed the standards are considered nonattainment areas. If there is insufficient information to classify an area as attainment or nonattainment, the area is designated as unclassifiable for a pollutant or group of pollutants. In 1990 the CAA underwent major amendments to expand its list of regulated chemicals and tighten regulations on such topics as acid rain, ozone depletion, and air toxins.

Alaska's Department of Environmental Conservation implements air quality regulations through its Division of Air and Water Quality. Within this division there are two air programs: Air Quality Maintenance which regulates air pollution emitted from industrial facilities, and Air Quality Improvement which is responsible for mobile sources of air contaminants, air quality monitoring, and radiation issues. To better manage air quality, Alaska is divided into four air quality control regions. Kotzebue is located in the Northern Alaska Intrastate Air Quality Control Region. While this region is considered in attainment for all criteria pollutants, Kotzebue is an area where no air monitoring has been conducted and is therefore designated unclassifiable.

There are two major stationary air sources in the Kotzebue region: the Red Dog mine, located approximately 80 miles north of Kotzebue, and the Kotzebue Electric Association located in Kotzebue proper. KEA recently received a Prevention of Significant Deterioration (PSD) 
permit for modifications made to its plant. Air quality modeling indicates that KEA's emissions are well within State standards for criteria air pollutants (Envirometrics, 1997). KEA currently operates one to two turbines at a load of approximately 80 to 100 percent per year.

\subsection{Cultural Resources}

Section 106 of the National Historic Preservation Act of 1966 requires Federal agencies to take into account the effects of their undertakings on historic properties. The identification and evaluation of cultural resource properties within the access road portion of the proposed project site are described in a Class 3 U.S. Department of the Interior, Bureau of Indian Affairs (USBIA) cultural resource report (USDOI, 1995). This report was commissioned by the USBIA Area Roads to determine potential impacts to cultural resources from constructing various roadways in the Kotzebue area. This report is considered germane to the proposed project since one of the roadways addressed in the USBIA report is within close proximity to the proposed access road. As described in the report, a records search was conducted to determine the nature and extent of prior archaeological investigations in the area, and assess their findings. As may be expected in this arctic landscape, previously recorded archaeological sites were sparse. Subsequent pedestrian surveys did not identify any unrecorded sites. However, two previously recorded sites (Kotzebue Archaeological District [AHRS \#KTZ-036] and the Kotzebue White Alice Communications Site [AHRS \#KTZ-037] located approximately 3 miles northwest and 0.75 miles west from the project site, respectively) and one archaeologically sensitive area were located in the Kotzebue area. The report concluded that no cultural resources were identified within the area affected by the various proposed roadways.

The proposed access road was the subject of a USACE 404 permit application as described in Section 3.3. As noted within the Permit Evaluation and Decision Document, no historic properties were associated with the access road site and no comments were received from the State Historic Preservation Office (USACE, 1997c).

\subsection{Noise}

Noise may be defined as any sound that annoys or disturbs humans or tends to cause an adverse psychological or physiological effect on humans (Lipscomb, 1978). Sound waves are 
characterized by sound pressure expressed as decibels (dB). To evaluate noise as it relates to humans, an A-weighted sound level is used (dBA). This measurement specifically includes the frequencies perceptible to the human ear and de-emphasizes those frequencies that humans cannot hear. The State of Alaska statutes were reviewed for applicable noise control requirements. While no specific noise levels were prescribed, the statutes restricted "excessive" or "nuisance" noise and included requirements to prevent adverse impacts to an area.

The existing noise environment in Kotzebue is influenced by two main contributors: the municipal airport directly south of Kotzebue and the prevalence of snow machines and all terrain vehicles as a main source of local transportation. With respect to the project site there are no features that generate noise, aside from the three existing wind turbines. Furthermore, the project site is located in an area devoid of sensitive receptors (residences, schools, hospitals, threatened and endangered species). 
This page left intentionally blank. 


\section{CHAPTER 4 \\ ENVIRONMENTAL IMPACTS}

The following chapter summarizes the potential environmental impacts from the proposed action and no action alternative.

\subsection{Biological Resources}

The potential impacts to the local biota from additional wind turbines would be related to any direct loss of wildlife habitat from construction or operation of the wind turbines or increased bird mortality from collisions with the turbine blades or towers.

\subsubsection{Vegetation}

Installation of the additional wind turbines would be conducted during the winter and in a manner so that there would be very little disruption of the vegetative tundra mat which covers the site. No fill material would be required for tower or building foundations. Therefore the effect on vegetation and wetlands would be expected to be minimized. Some compression or disruption of vegetation may occur in some areas from ground activity around the tower foundations. However, the overall vegetation cover of the site should not be adversely affected. Impacts to vegetation would be expected to be negligible.

\subsubsection{Birds}

Direct impacts to birds would be the loss of a small amount of wet tundra habitat from construction of the towers and the potential effect of collisions with the turbine blades. The loss of habitat would only affect a relatively small number of nesting birds (e.g. lapland longspur, sandpiper) which would be unable to adapt to the construction and operational activities or the presence of structures within their breeding territories. Birds presently nesting near or at the site would be displaced by the proposed activities, but would likely use adjacent habitat.

The effects of bird collisions with wind turbine blades has received considerable attention at large wind generation sites such as Altamont Pass and Tehachapi Pass in California. Studies have indicated a great deal of variability among sites with respect to bird strikes, but several 
factors contribute to the rate of collision. These factors include: weather, the number of birds flying through the site, flight altitude of the birds, the probability of a bird entering the areas swept by the turbine blades, and the number and height of operating turbines (D\&M, 1997). Most of these studies have indicated that raptors are the species most affected by the collisions and may be associated with the raptors attention on hunting for rodents in areas around the turbines. Raptors are relatively uncommon in the Kotzebue area and any collisions with the turbine blades would likely be to individual birds which would not affect the local population.

Since there are no major migratory staging areas for waterfowl or shorebirds in the immediate area of the site, and no major geographic features which concentrate birds within a migratory corridor near the site, effects on migratory species are not anticipated. Local breeders in the surrounding areas are more likely to be at some risk, and the greatest risk would be during periods of poor visibility or inclement weather. Overall, the potential impacts to birds would most likely be limited to the occasional individual colliding with a turbine. These isolated collisions are not expected to affect the local population. As a special condition to the USACE permit, an avian survey is to be conducted on birds found at the wind installation site or flying in close proximity to the wind installation during one spring and one fall migration period (USACE, 1997c).

\subsubsection{Mammals}

The proposed project's effects on wildlife would be a slight reduction of available habitat for the occasional caribou which may move through the area during the winter. This loss of habitat would be expected to have no adverse effect on any of the species using the area because of the abundance of similar habitat surrounding the site.

\subsubsection{Threatened and Endangered Species}

Spectacled and Steller's Eiders are not expected to occur in the immediate area during migration or during the nesting season; therefore, they are not expected to be affected by an increased number of wind turbines at the site. 


\subsection{Land Use}

In assessing land use impacts, the proposed action was evaluated for consistency with land use plans or guidance, and compatibility with current and future land uses. As stated in Section 3.2 , there are no land use plans that govern KIC property. Therefore, it is not possible to evaluate the project with consistency to planned land use. However, according to $\mathrm{KIC}$, the wind installation is considered the best use for the land. With respect to land use compatibility, there are some existing features with which to compare potential land use conflicts, namely the potential for airport relocation, the KOTZ radio tower, and the Kotzebue landfill.

As mentioned in section 3.2 , the airport relocation alternative is very unlikely. In the remote chance that the airport is relocated to an area south and east of the current wind installation, potential impacts would be limited to airspace and runway obstruction and possible electromagnetic interference with the aircraft landing systems. With respect to airspace and runway obstruction, runways at Kotzebue are oriented east/west as these are the prevailing wind directions. Since the wind installation is located north of the proposed alternative location, potential conflict with runway space required for take-offs and landings would not be expected. There are FAA regulations for structures alongside runways. Based on conversations with $\mathrm{ADOT}$, the wind turbines could limit future runway locations, but in no way would preclude the relocation alternative since the alternative would still would have to consider compatibilities with the three existing turbines. Since the preferred alternative consists of redevelopment within the airport's existing land, there would be no conflict in land use from installing additional turbines at the existing wind installation (ADOT, 1998).

Other potential conflicts with current land use include the ways in which the wind turbines could possibly interfere with any type of electromagnetic (radio) transmission. The systems of interest include the KOTZ radio antenna, the airport's instrument landing system, and the unmanned White Alice Communication station. The National Renewable Energy Laboratory (NREL) conducted a study to address potential electromagnetic interference (EMI) from the wind turbines. The conclusions from the study are specific to AM broadcasting reception, FM/TV broadcasting, aircraft navigation, cellular telephones, and the Air Force RADAR installation. 
It is expected that very little reradiation and essentially no interference will occur with the KOTZ radio broadcast (NREL, 1998). Currently, there is no cellular phone service or conventional FM or TV broadcasting stations in the area, therefore interference with these systems is not expected. Satellite dish antennas have very narrow beam widths and are oriented towards specific satellites. Because of the wind installation's remote location, no interference is expected. The Kotzebue airport has not reported any interference with their navigation systems related to the existing wind turbines. Furthermore, no signal degradation is expected because the system uses narrow beam widths and is relatively far from the wind site. Like navigation systems, radar antennas also use a very narrow beam width for measuring directions accurately. Potential impacts to the White Alice Communication station are considered unlikely, as reception of interfering signals from outside that beam is nearly impossible (NREL, 1998).

\subsection{Impacts to the Coastal Zone}

While the wind installation site is located approximately 0.5 miles from the coast, it does not exhibit any coastal habitat as defined in the ACMP, except for wetlands. As mentioned in Sections 2.4 and 3.3, the USACE and the Alaska DGC reviewed and approved the access road application which allows approximately $8000 \mathrm{yds}^{3}$ of fill material to be placed in wetland habitat adjacent to the wind installation. The access road proposal was found to be consistent with the ACMP and would not adversely impact resources in the area.

By comparison, the wind installation expansion would not require any filling in of wetlands nor displace any unique or sensitive habitats. KEA would perform all construction activities while the tundra is frozen to minimize impacts to the vegetation. Wind turbine operation would not produce any effluents or emissions, and with respect to visual impacts, the site is not visible from the sea or coastal beaches (KEA, 1997).

\subsection{Air Quality}

The proposed construction and operation of 20 wind turbines would result in a small amount of construction equipment emissions from boring piling holes and raising the towers. As described in Section 2.5, construction equipment will operate on an intermittent basis throughout 
this project. Because construction equipment would be running very infrequently, resultant air emissions would be well dispersed are not expected to adversely affect air quality.

Wind turbine operation would not produce any air emissions. The use of wind energy to supplant the use of diesel power would, in effect, reduce air pollutants by reducing the reliance on combustion engines currently used to generate electricity. Based on KEA's current operations and the assumption that wind power would replace approximately 2.5 million kwh per year (roughly 13 percent), it is estimated that KEA would be able to reduce criteria pollutants by approximately $200,000 \mathrm{lbs}$ per year.

\subsection{Cultural Resources/Human Environment}

Cultural resource concerns specific to the proposed project site were addressed during a consultation with the State Historic Preservation Office and the DOE during an informal meeting in November 1997. According to Mr. Tim Smith, archaeologist, the project site would be likely devoid of any unrecorded historic properties and is considered to be low in cultural resource sensitivity. This finding is based upon the lack of findings from previous cultural resource studies in the project area, and the location of the project being sited within a former lake bed area which would not have been expected to support previous human activity.

With respect to Native American concerns in the project area, the DOE met with Mr. Pete Schaeffer, Executive Director of the Native Village of Kotzebue IRA, the tribal government serving the people of the Kotzebue area, to inform him of the project and to gather information regarding cultural sensitivity of the area proposed for project development. According to $\mathrm{Mr}$. Schaeffer, the project area is not considered to possess any unique ethnic cultural value and is not used for subsistence or religious purposes.

\subsubsection{Environmental Justice}

In 1994, the President issued an Executive order to focus Federal attention on the environmental and human health conditions in minority and low income communities with the goal of achieving environmental justice. The purpose of environmental justice is to ensure that no segment of the population, regardless of race, ethnicity, or income, bears disproportionately high 
and adverse effects of environmental pollution. The expansion of the Kotzebue wind installation would not result in any air or noise emissions, liquid effluents, or solid waste. The site is not visible from Kotzebue nor the coastal areas adjacent to the site. The expansion of the wind installation would, however, decrease the consumption of diesel fuel, decrease air emissions, and ideally keep electricity costs from escalating. The potential benefits from the proposed project would be distributed equally to all Kotzebue residents. Consequently, the proposed project would not be expected to result in unfair or unequal treatment of any low income or impoverished communities or populations.

\subsection{Noise}

Noise generation as a result of the project is expected from construction, operation, and maintenance activities at the wind installation. Daily turbine operation is expected to generate the worst case and long-term noise conditions.

Wind turbine installation is expected to generate noise primarily from internal combustion engines used to power the construction equipment. Specific noise generation and characterization depends on the type of equipment used, the amount of equipment operating simultaneously, and hours of operation. It is anticipated that typical construction equipment will be used and that the hours of operation would occur only during normal working hours. As described in Section 2.5, it is anticipated that the construction period will be a relatively short time period. Because of the noise standards that construction equipment manufactures are required to adhere to, it is not anticipated that excessive or unusual noise generation will result from the construction operations. In addition, assuming the construction operations occur only during normal working hours, it is anticipated that the noise generation will not have any adverse impacts to offsite receptors.

Using reasonably conservative assumptions, noise levels of the AOC 15/50 wind turbine were estimated to be $104 \mathrm{dBA}$ at the turbine hub with an 18 mile per hour wind (NREL 1997). Based on other vender data and information, this noise level appears to be relatively high for modern wind turbines, but was used as a conservative basis for the purposes of this noise assessment. Assuming a relatively high noise level as a basis will help ensure a conservative assessment of the potential noise impacts from the proposed project. 
The ambient sound level at the ground surface was estimated to be $75 \mathrm{~dB}(\mathrm{~A})$ assuming 10 or more wind turbines operating simultaneously (see Appendix). This sound level is below the federal standard of $85 \mathrm{dBA}$ for occupational hearing conservation programs. Operation-related noise levels were estimated for distances further away from the project site and are shown in the table below.

Table 1 Operation-Related Noise Level Estimates

\begin{tabular}{cc}
\hline Noise Level (in dBA) & At Distance (in meters) \\
\hline 75 & 24 \\
63 & 100 \\
49 & 500 \\
43 & 1000 \\
37 & 2000 \\
33 & 3219 (landfill) \\
29 & 5000 \\
27 & 6437 (airport) \\
26 & 7242 (Kotzebue) \\
\hline
\end{tabular}

The following three examples put noise level estimates into perspective: normal conversation at approximately one meter has a sound pressure of approximately $60 \mathrm{dBA}$; a quiet office has a sound pressure of approximately $50 \mathrm{dBA}$ and is considered quiet; and finally a soft whisper at five meters is approximately $30 \mathrm{dBA}$ and is considered very quiet (Lipscomb, Taylor, 1978). Based on the estimated noise levels it is not anticipated that significant noise emissions would result from the operation of the wind installation.

\subsection{No Action Alternative}

Without the expansion of the existing wind installation, Kotzebue would continue to use diesel generators for electric power and purchase additional wind turbines if and when funds are available. Impacts from the no action alternative include the loss of wind turbine testing data under Arctic conditions and the continued consumption of diesel fuel and subsequent production of air emissions. As other rural communities would potentially benefit from the information gathered from the test installation, the no action alternative would preclude or substantially delay the application of wind technology to these communities. 
This page left intentionally blank. 


\section{CHAPTER 5 \\ CUMULATIVE IMPACTS}

This section examines the cumulative environmental effects which would result from adding the impacts of the proposed action to the impacts from past, present, and reasonably foreseeable activities in the Kotzebue area. At the time of this assessment, there are no current or proposed actions that, combined with the proposed project, would contribute to cumulative impacts in the Kotzebue area.

As described in Chapter 4, there are only a couple of environmental categories where the proposed action could cause potential impacts, namely habitat disturbance and bird strikes. The minor disturbance to wetland habitat would not adversely affect the availability of wetland habitat in the area. Furthermore, no other construction projects were forecasted near the wind installation site. While isolated bird strikes may occur, there are no other identified projects which would also contribute to bird mortality. The largest contributor to air emission in the vicinity is KEA and arguably the airport. The proposed project is not only devoid of air emissions, but would function to reduce air emissions from the diesel generators. The project does not produce liquid effluents or solid waste. Increased noise from the wind installation would be indiscernible from other background noises, namely the airport. 
This page left intentionally blank. 


\section{CHAPTER 6}

\section{REFERENCES}

ADOT (Alaska Department of Transportation), 1998. Personal communication between N. Piispanen (ADOT) and E. Lurier (Dames \& Moore), January 6, 1998.

Advanced Wind Turbines, Inc., 1997. Personal communication with E. Lurier (Dames \& Moore), December 8, 1997.

Dames \& Moore, 1997 Biological Assessment for the Kotzebue Wind Farm Project, Kotzebue, Alaska, Project No. 30822-112 for the Department of Energy, Golden Field Office, December 1997.

DCG (Division of Governmental Coordination, State of Alaska), 1997. Final Consistency Determination. Letter from Maureen McRae (DGC) to Bish Gallahorn (KIC), July 15, 1997.

Envirometrics, 1997. Facsimile to E. Lurier (Dames \& Moore), KEA air emissions, December 16 and December 22, 1997.

Expert Group Study 1994. Expert Group Study on Recommended Practices For Wind Turbine Testing And Evaluation, 4. Acoustics Measurement of Noise Emission From Wind Turbines, 3. Edition 1994.

KEA (Kotzebue Electric Association), 1997. Proposal from KEA to DOE-GO.

Lipscomb and Taylor, 1978. Noise Control Handbook of Principles and Practices, Van Nostrand Reinhold Environmental Engineering Series, 1978.

NOAA (National Oceanic and Atmospheric Administration), 1994. Local Climatological Data , Annual Summary with Comparative Data, Kotzebue, Alaska. 
NREL (National Renewable Energy Laboratory) 1998. Memo from G. Nix to E.Lurier (Dames \& Moore). Information regarding electromagnetic interference and acoustics, January 20, 1998.

Reeve, Brad, 1997(a). Personal Communication. E. Lurier (Dames \& Moore) with Brad Reeve, General Manager, Kotzebue Electric Association.

Selkregg, L. 1976.Alaska Regional Profiles - Northwest Region. State of Alaska and Joint Federal-State Land Use Planning Commission for Alaska, Juneau, AK.

USACE (U.S. Army Corps of Engineers), 1997a. Permit No. 4-970322, Kotzebue Sound 60 issued to Kikiktagruk Inupiat Corporation (KIC) for the construction of a 0.7 mile access road, July 31, 1997.

USACE, 1997b. Letter from Allan Skinner (USACE) to Percy Frisby (Alaska Department of Community and Regional Affairs, Division of Energy), September 5, 1997.

USACE, 1997c. Permit Evaluation and Decision Document for Kikiktagruk Inupiat Corporation, No. 4-970322, July 18, 1997

USDOI, (U.S. Department of the Interior), Bureau of Indian Affairs, The Kotzebue Road Project Proposal, Project \# 51(1), A Cultural Resource Report of Investigations and \& Section 106 Review. Prepared for the State Historic Preservation Office, Alaska Department of Natural Resources, January 1995. 


\section{CHAPTER 7 \\ LIST OF AGENCIES AND PERSONS CONSULTED}

The following is a list of persons and agencies who provided the information necessary to write this environmental assessment:

Brad Reeve - General Manager, Kotzebue Electric Association

Craig Thompson - Thompson Engineering Company

Mark Koepsel - Alaska Department of Fish and Wildlife

Pete Schaeffer - Executive Director, Kotzebue IRA

Allan Skinner - Regulatory Specialist, U.S. Army Corps of Engineers

Michael O'Connor - Acting President, Kikiktagruk Inupiat Corporation

Wilfred Lane - Land Manager, Kikiktagruk Inupiat Corporation

Timothy Smith - Archaeologist, Alaska Department of Natural Resources, Office of History and Archaeology

Robert Poore - Advanced Wind Turbines, Inc.

Jim Baumgartner - Alaska Division of Air and Water Quality

Norm Piispanen - Alaska Department of Transportation

Jeff Davis - Alaska Division of Governmental Coordination

Dennis Meiners - Division of Energy, Alaska Department of Community and Regional Affairs 


\section{APPENDIX A}

\section{SCOPING LETTERS}




\section{Department of Energy \\ Golden Field Office \\ 1617 Cole Boulevard \\ Golden, Colorado 80401-3393}

February 12,1998

\section{DISTRIBUTION LIST}

\section{SUBJECT: NOTICE OF SCOPING - ENVIRONMENTAL ASSESSMENT FOR KOTZEBUE EXPERIMENTAL WIND FARM PROJECT, KOTZEBUE, ALASKA}

The United States Department of Energy's (DOE) Golden Field Office (GO) is proposing to partially fund the development of an experimental test wind farm located in Kotzebue, Alaska. The proposed wind farm is intended to test commercially available turbines in extreme Arctic conditions in order to evaluate turbine performance and reliability under a wide range of temperatures, precipitation events and strong Arctic winds. This information would be useful in applying wind power technology in other locations subjected to extreme weather conditions.

It is DOE's policy to integrate community and public concerns into its decision making process Accordingly, prior to undertaking the action described above, $\mathrm{GO}$ will be preparing an Environmental Assessment (EA) to evaluate the potential environmental impacts of the construction and operation of the proposed wind farm. On November 4-5, 1997, representatives of our office conducted a site visit and held informal meetings with you or representatives of your organization. During our discussions, interest was expressed by various parties in the following areas: visual aesthetics, avian impacts, potential cost savings and design life of the facility. Please see the attachment to this letter of a list of other organizations contacted.

The town of Kotzebue and the proposed location of the experimental wind farm are both located within the bounds of a designated wetland area. Therefore, $G O$ will be posting a Notice of Wetland Involvement in the Federal Register as required by DOE's Compliance with Floodplain/Wetlands Environmental Review Requirements (10 CFR Part 1022). The discussion of the potential impacts to the wetlands and reasonable alternatives will be incorporated into the EA being prepared under DOE NEPA regulations.

Please direct any additional comments, questions or concerns you may have regarding this proposal to Deborah Turner, NEPA Compliance Officer, Golden Field Office by February 27, 1998. The draft EA document will be provided to your organization as well as other interested parties for review and comment upon its completion. All responses will be considered prior to $\mathrm{DOE}$ reaching a final decision regarding funding of the proposed project. 
Thank you for your interest and participation in our process. Should you have any questions, please contact Deborah at (303) 275-4746.

Sincerely,

Frank M. Stewart

Manager

Attachment:

As Stated

$\mathrm{cc}$ w/distribution list:

D. Turner, GO

C. McDonough, G/M

E. Lurier, Dames \& Moore 
Mr. Daniel Kirshner

Senior Analyst

West Coast Office

Environmental Defense Fund, Inc.

5655 College Avenue

Suite 304

Oakland, CA 94618

Mr. John Schoen

Executive Director

Alaska State Office

National Audubon Society

308 G Street

Suite 217

Anchorage, AK 99501

Mr. Randall H. Hagenstein

Associate State Director

Alaska Field Office

The Nature Conservancy

421 West First Avenue

Suite 200

Anchorage, AK 99501

Mr. Jack Hession

Alaska Representative

Alaska Office

Sierra Club

241 East 5th Avenue

Suite 205

Anchorage, AK 99501

Ms. Marguerite Young

State Program Director

West/Northwest Region

Clean Water Action

944 Market Street

Suite 600

San Francisco, CA 94102

The Honorable Tony Knowles

Governor of Alaska

P.O. Box 110001

Juneau, AK 99811-0001
Ms. Diane Mayer, Director,

Division of Environmental Coordination

Office of the Governor

P.O. Box 110030

Juneau, AK 99811-0030

Mr. Willie R. Taylor, Director

Office of Environmental Policy and

Compliance

U.S. Department of the Interior

1849 C Street, NW

Room 2340

Washington, DC 20240

Ms. Ann M. Hooker

Environmental Specialist/NEPA Liaison

Office of Energy and Environment

Federal Aviation Administration

U.S. Department of Transportation

AEE300 -- Room 902

800 Independence Avenue, SW

Washington, DC 20591

Mr. Rick Parking (ECO-088)

Unit Manger, Geographic

Implementation Unit

Office of Ecosystems and Communities

Region 10

U.S. Environmental Protection Agency 1200 Sixth Avenue

Seattle, WA 98101 
Mr. Ronald J. Morris

Western Alaska Office Supervisor

Protective Resources Mgt Division

U.S. Department of Commerce

National Oceanic and Atmospheric

Administration

National Marine Fisheries Service

$222 \mathrm{~W} 7$ th Avenue, \#43

Anchorage, AK 99513-7577

Colonel Peter A. Topp

District Engineer, Alaska District

U.S. Army Corps of Engineers

P.O. Box 898

Anchorage, AK 99506-0898

Mr. Larry K. Bright

Acting Field Supervisor

U.S. Department of Interior

Fish and Wildlife Service

Northern Alaska Ecological Services

101 12th Ave., Box 19, Rm 110

Fairbanks, AK 99701

Mr. Paul Bateman

Alaska Department of Environmental

Conservation

610 University Ave.

Fairbanks, AK 99709-3643

Victor Karmun

Northwest Arctic Borough

Coastal District

P.O. Box 1110

Kotzebue, AK 99752

Refuge Manager

Selawik National Wildlife Refuge

P.O. Box 270

Kotzebue, AK 99752
Mr. Randi Meyers

Bureau of Land Management

Kotzebue Office

P.O. Box 1049

Kotzebue, AK 99752

Director

Bureau of Land Management

Northern District Office

1150 University Avenue

Fairbanks, AK 99709-3899

Frank Green, Mayor

City of Kotzebue

P.O. Box 46

Kotzebue, AK 99752

Chuck Green, Mayor

Northwest Arctic Borough

P.O. Box 1110

Kotzebue, AK 99752

Lt. Col. David T. Peters

6900 9th. Street

Suite 360

Elmendorf Air Force Base, AK 99506

Mr. Pierre Lonewolf

General Manager

Kotzebue Broadcasting, Inc.

P.O. Box 78

Kotzebue, AK 99572

NANA Regional Corporation

P.O. Box 49

Kotzebue, AK 99752 


\section{Department of Energy \\ Golden Field Office \\ 1617 Cole Boulevard \\ Golden, Colorado 80401-3393}

February 12, 1998

\section{DISTRIBUTION LIST}

\section{SUBJECT: NOTICE OF SCOPING - ENVIRONMENTAL ASSESSMENT FOR KOTZEBUE EXPERIMENTAL WIND FARM PROJECT, KOTZEBUE, ALASKA}

The United States Department of Energy's (DOE) Golden Field Office (GO) is proposing to partially fund the development of an experimental test wind farm located in Kotzebue, Alaska. The proposed wind farm is intended to test commercially available turbines in extreme Arctic conditions in order to evaluate turbine performance and reliability under a wide range of temperatures, precipitation events, and strong Arctic winds. This information would be useful in applying wind power technology in other locations subjected to extreme weather conditions.

It is DOE's policy to integrate community and public concerns into its decision making process. Accordingly, prior to undertaking the above described action, GO will be preparing an Environmental Assessment (EA) to evaluate the potential environmental impacts of the construction and operation of the proposed wind farm. As part of the EA development, public and other agency input is being sought by means of this letter. On November 4-5, 1997, representatives of our office conducted a site visit and held informal meetings with several State and local organizations. Unfortunately, scheduling conflicts did not allow our representatives to meet with all interested or potentially affected parties. Please see Attachment A to this letter for a list of the organizations contacted.

The town of Kotzebue and the proposed location of the experimental wind farm are both located within the bounds of a designated wetland area. Therefore, $\mathrm{GO}$ will be posting a Notice of Wetland Involvement in the Federal Register as required by DOE's Compliance with Floodplain/Wetlands Environmental Review Requirements (10 CFR Part 1022). The discussion of the potential impacts to the wetlands and reasonable alternatives will be incorporated into the EA being prepared under DOE NEPA regulations.

Please direct any comments, questions or concerns you may have regarding this proposal to Deborah Turner, NEPA Compliance Officer, Golden Field Office by February 27, 1998. The draft EA document will be provided to interested parties for review and comment upon its completion. All responses will be considered prior to DOE reaching a final decision regarding funding of the proposed project. 
Thank you for your interest and participation in our process. Should you have any questions, please contact Deborah at (303) 275-4746.

Sincerely,

Manager

Attachment:

As Stated

cc w/distribution list:

D. Turner, GO

C. McDonough, $\mathrm{G} / \mathrm{M}$

E. Lurier, Dames \& Moore 
Mr. Mike Connor, Acting

President

Kikiktagruk Inupiat Corporation

P.O. Box 1050

Kotzebue, AK 99752

Mr. Wilford Lane, Land Manager

Kikiktagruk Inupiat Corporation

P.O. Box 1050

Kotzebue, AK 99752

Mr. Pete Schaeffer

Executive Director

Native Village of Kotzebue

Kotzebue IRA

P.O. Box 296

Kotzebue AK 99752

Mr. Alex Whiting

Environmental Contact

Native Village of Kotzebue

Kotzebue IRA

P.O. Box 296

Kotzebue AK 99752

Mr. Allan G. Skinner

Regulatory Specialist

US Army Corps of Engineers

Alaska District

Regulatory Branch

P.O. Box 898

Anchorage, AK 99506-0898

Mr. Timothy A. Smith

Archaeologist

Department of Natural Resources

Divisions of Parks \& Outdoor

Recreation

Office of History and

Archaeology

3601 C Street, Suite 1278

Anchorage, AK 99503-5921

SHPO Office

Anchorage, AK
Ms. Maureen McCrea

Mr. Jeff Davis

Division of Governmental

Coordination

Office of Management and

Budget

Southcentral Regional Office 3601 C Street

Suite 370

Anchorage, AK 99503-2798 


\section{APPENDIX C}

EA DISTRIBUTION LETTERS AND COMMENTS 


\section{Department of Energy \\ Golden Field Office \\ 1617 Cole Boulevard \\ Golden, Colorado 80401-3393 \\ March 24, 1998}

\section{DISTRIBUTION LIST}

\section{SUBJECT: PREDECISIONAL DRAFT ENVIRONMENTAL ASSESSMENT OF THE KOTZEBUE WIND INSTALLATION PROJECT, KOTZEBUE, ALASKA (DOE/EA-1245)}

In October 1997, the U. S. Department of Energy's Golden Field Office (GO) began an evaluation of providing partial funding for the Kotzebue Wind Installation to test commercially available turbines in extreme Arctic conditions in order to evaluate turbine performance and reliability under a wide range of temperatures, precipitation events and strong Arctic winds. As part of this evaluation, GO undertook the preparation of an environmental assessment for the proposed project to be located in Kotzebue, Alaska. In November 1997, representatives of GO conducted a site visit and met with various Inuit tribal, state, and local representatives. In February 1998, a formal request for input on the proposed project was conducted through the issuance of Notice of Scoping letters to Federal, state, and local regulatory bodies, and other potential interested parties. A description of the proposed project, environmental analyses including potential impacts, potential wetlands impacts and comments from interested parties have been integrated into the Predecisional Draft Environmental Assessment.

It is DOE's policy to integrate community and public concerns into its decision making process. Therefore, by this letter, notice of the availability of the Predecisional Draft Environmental Assessment for the Kotzebue Wind Installation is being provided to your organization. If you are interesting in obtaining a copy for review please contact our office. Comments should be provided to Deborah Turner, NEPA Compliance Officer, by May 8, 1998. Once comments have been received, reviewed and addressed, a final Environmental Assessment will be issued. If you are interested in receiving a copy of the final document, please let Deborah know. Deborah can be reached by phone (303) 275-4746, fax (303) 275-4788, email deborah_turner@nrel.gov or the above address. Thank you for your interest and participation in our process.

Sincerely,

Frank M. Stewart

Manager

cc:

D. Turner, GO

- E. Lurier, D\&M 
Mr. Daniel Kirshner

Environmental Defense Fund, Inc.

5655 College Ave, Suite 304

Oakland, CA 94618

Mr. Randall Hagenstein

The Nature Conservancy

421 West First Ave., Suite 200

Anchorage, AK 99501

Ms. Marguerite Young

Clean Water Action, West/Northwest Region

944 Market Street, Suite 600

San Francisco, CA 94102

Ms. Ann Hooker

U.S. Deparment of Transportation

Office of Energy and Environment

AEE300---Room 902

800 Independence Ave., SW

Washtington, DC 20591

Uf Ronid J Nowion

U.S. Department of Commerce

$222 \mathrm{~W}$. 7 th Ave., $\# 43$

Anchorage, AK 99513-7577

Mr. Paul Bateman

Alaska Department of Environmental Conservation

610 University Ave.

Fairbanks, AK 99709-3643

Mr. Randi Meyers

Bureau of Land Management

Kotzebue Office

P.O. Box 1049

Kotzebue. AK 99752
Mr. John Schoen

National Audobon Society

308 G Street, Suite 217

Anchorage, AK 99501

Mr. Jack Hession

Sierra Club, Alaska Office

241 East 5 th Ave., Suite 205

Anchorage, AK 99501

Mr. Willie R. Taylor

U.S. Department of the Interior 1849 C Street, NW, Room 2340

Washington, DC 20240

Mr. Rick Parking

U.S. Environmental Protection Agency 1200 Sixth Ave.

Seattle, WA 98101

Cuiunei Feted A. Topp

U.S. Army Corps of Engineers

P.O. Box 898

Anchorage, AK 99506-0898

Mr. Victor Karmun

Northwest Arctic Borough

P.O. Box 1110

Kotzebue, AK 99752

Director

Bureau of Land Management

1150 Univiversity Avenue

Fairbanks, AK 99709-3899 
c. Col. David T. Peters

\$00 9th Sireet, Suite 360

lmendorf Air Force Base, AK 99506 


\section{Department of Energy \\ Golden Field Office \\ 1617 Cole Boulevard \\ Golden, Colorado 80401-3393}

March 24, 1998

\section{DISTRIBUTION LIST}

\section{SUBJECT: PREDECISIONAL DRAFT ENVIRONMENTAL ASSESSMENT FOR KOTZEBUE EXPERIMENTAL WIND INSTALLATION PROJECT, KOTZEBUE, ALASKA (DOE/EA-1245)}

In October 1997, the U. S. Department of Energy's Golden Field Office (GO) began an evaluation of providing partial funding for the Kotzebue Wind Installation to test commercially available turbines in extreme Arctic conditions in order to evaluate turbine performance and reliability under a wide range of temperatures, precipitation events and strong Arctic winds. As part of this evaluation, GO undertook the preparation of an environmental assessment for the proposed project to be located in Kotzebue, Alaska. In November 1997, representatives of GO conducted a site visit and met with various Inuit tribal, state, and local representatives. In February 1998, a formal request for input on the proposed project was conducted through the issuance of Notice of Scoping letters to Federal, state, and local regulatory bodies, and other potential interested parties. A description of the proposed project, environmental analyses including potential impacts, potential wetlands impacts, and comments already expressed to $\mathrm{GO}$ by various parties have been integrated into the Predecisional Draft Environmental Assessment for the Kotzebue Wind Installation Project.

It is DOE's policy to integrate community and public concerns into its decision making process. Therefore, the Predecisional Draft Environmental Assessment for the Kotzebue Wind Installation is being provided to your organization for review and comment. Please provide any comments to Deborah Turner, NEPA Compliance Officer, by May 8, 1998. Once comments have been received, reviewed and addressed, a final Environmental Assessment will be issued. If you are interested in receiving a copy of the final document, please let Deborah know. Deborah can be reached by phone (303) 275-4746, fax (303) 275-4788, email deborah_turner@nrel.gov or the above address. Thank you for your interest and participation in our process.

Sincerely,

Frank M. Stewart

Manager

Enclosure:

As Stated

cc w/address list:

D. Turner, GO

E. Lurier, Dames \& Moore 
Wr. Mike Connor

Kikiktagruk Inupiat Corporation

P. O. Box 1050

Kotzebue, AK 99752

vir. Pete Schaeffer

Vative Village of Kotzebue

Kotzebue IRA

?.O. Box 296

otzebue, AK 99752

Ir. Allan G. Skinner

iS Army Corps of Engineers, AK District

O. B. Box 898

inchorage, AK 99506-0898

s. Maureen McCrea / Mr. Jeff Davis

ivision of Governmental Coordination

:601 C Street, Suite 370

schorage, AK 99503-2798

The Honcrable Tony Knowles

jovernor of Alaska

$\therefore$ O. Box 110001

Juneau, IK 99811-0001

Frank Green, Mayor

Ciry of Kotzebue

P.O. Box 46

Kotzebue, AK 99752

VANA Regional Corporation

?.O. Box 49

Kotzebue, AK 99752
Mr. Wilford Lane

Kikiktagnuk Inupiat Corporation

P.O. Box 1050

Kotzebue, AK 99752

Mr. Alex Whiting

Native Village of Kotzebue

Kotzebue $\mathbb{R A}$

P.O. Box 296

Kotzebue, AK 99752

Mr. Timothy Smith

Department of Natural Resources

Division of Parks \& Outdoor Recreation

3601 C Street, Suite 1278

Anchorage, AK 99503-5921

Ms. Diane Mayer

Office of the Governor

Division of Environmental Coordination

P.O. Box 110030

Juneau, AK 99811-0030

ivi. Larry $\overline{\mathrm{n}}$. Bright

U.S. Department of Interior

Fish and Wildlife Service

101 12th Ave., Box 19, Room 110

Fairbanks, AK 99701

Chuck Green, Mayor

Northwest Arctic Borough

P.O. Box 1110

Kotzebue, AK 99752

Mr. Pierre Lonewolf

Kotzebue Broadcasting, Inc.

P.O. Box 78

Kotzebue, AK 99752 
ir. Paul Gates

S. Department of Interior

589 C Street, Room 119

nchorage, AK 99501-5126 


\section{United States Department of the Interior}

FISH AND WILDLIFE SERVICE

NORTHERN ALASKA ECOLOGICAL SERVICES

$10112^{\text {th }}$ Ave., Box 19, Room 110

Fairbanks, AK 99701

May 11, 1998

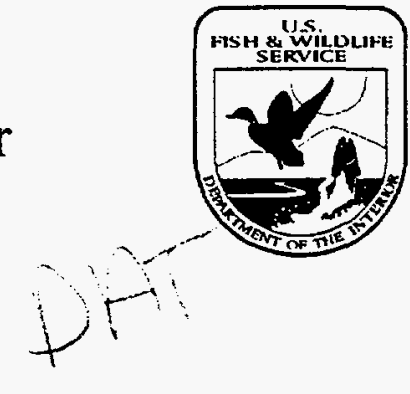

Debra A. Turner

NEPA Compliance Officer

U.S. Department of Energy

Golden Field Office

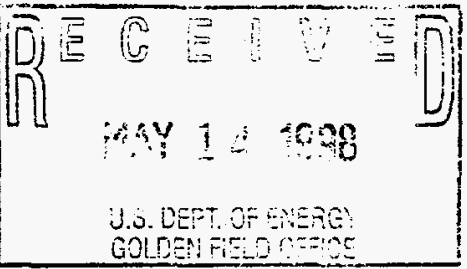

1617 Cole Boulevard

Golden, Colorado 80401-3393

\section{Re: Predecisional Draft Environmental Assessment for the Kotzebue Experimental Wind Installation Project, Kotzebue, Alaska}

Dear Ms. Turner:

The Fish and Wildlife Service has reviewed the draft Environmental Assessment (EA) for the Kotzebue Wind Farm Project. In an effort to provide a cost-effective and clean source of electricity to Alaskan villages dependent upon diesel-powered generators, the Golden (CO) Field Office of the Department of Energy plans to test commercially available turbines in extreme Arctic conditions to evaluate turbine performance and reliability under a wide range of temperatures, precipitation events, and strong Arctic winds.

The 148-acre project site is located 4.5 miles south of Kotzebue, Alaska in moist tundra at an elevation of 50 feet above sea level. The project consists of installing, operating, and maintaining up to 20 wind turbines and ancillary equipment. Three different turbines will be tested, and will vary in size, power rating, and spacing requirements. The heights will vary for each model ranging from 107 feet to 186 feet. The wind turbine tower units will be erected on pilings placed 25 to 30 feet deep to anchor the structure and to prevent significant temperature changes in the permafrost.

Although the document describes the types of potential impacts to public trust resources, it lacks information that would allow adequate assessment of the extent of impacts to these resources by the proposed project. Diagrams and illustrations would have helped those unfamiliar with such devices and facilities to get a better understanding of the project. Answers are needed for a number of questions that would clarify or provide information pertinent to assessing the extent of impacts. These are as follows:

- $\quad$ Although the height of the units varied from 107 to 186 feet, it was unclear whether this was the height of the tower at the top of the turbine or the blade at the top of its rotating circumference. 
- What are the spacing requirements and what governs it? How will the 20 towers be distributed over the 148 -acre project site?

- $\quad$ According to the National Weather Service (personal communication), heavy fog occurs fairly frequently in Kotzebue during April, May and June, and less so in August and September. Are the towers lighted in any way for aviation or other needs? If so, could the lighting be an attraction to birds in fog or bad weather during migration or other periods?

- Would there be guy wires attached to support the towers?

- Would the visible action of the turbine blades have an impact upon wildlife use of adjacent habitats or modify their movement patterns?

- Noise was adequately described and assessed for one model turbine, the AOC $15 / 50$, in an $18 \mathrm{mph}$ wind; its noise level was $104 \mathrm{dBA}$. According to the National Weather Service, Kotzebue often experiences winds greater than $18 \mathrm{mph}$. Winds usually become stronger in the afternoon and evening. Does the noise level increase with stronger winds or gusts, say at 25 to $50 \mathrm{mph}$ winds?

The Species List in Appendix D is inadequate. For example, the document states (p. 14) that the common shorebirds in the Kotzebue area include over 30 species of migrants and breeders, yet there are only four listed in the Species List. The list in the Appendix should be as complete as possible, and the text should describe the general fauna and flora, with more detailed information about those species considered to be most important or most likely to be affected by the project.

The document states that the potential environmental impacts from the proposed expansion of the wind farm could include some loss of wildlife habitat from construction and operation of the turbines, and increased bird mortality from collisions with the turbine blades and towers. In the opinion of the Service, several other questions should be addressed as indicated above and information included in the EA for analysis prior to reaching conclusions regarding the potential extent of the impacts to public trust resources, particularly migratory birds.

The Service had requested monitoring of bird carcasses and birds flying near the wind farm site to be accomplished during one spring and fall migration as a condition on the U.S. Army Corps of Engineers 404 permit (4-970322) required for the construction of the proposed project. We continue to stress the importance of a monitoring program at the wind farm site, since it is a new type of construction in Alaska with potential for impacting migratory birds.

Threatened and endangered species

The proposed project is within the range of two species listed under the Endangered Species Act of 1973, as amended: the threatened spectacled eider (Somateria fischeri), and the threatened Alaska breeding population of the Steller's eider (Polysticta stelleri).

Spectacled eiders were listed as a threatened species under the Act on May 10, 1993. The population in Alaska declined approximately $96 \%$ between the 1970 's and the 1990 's. The 
current worldwide population estimate is 360,000 birds. This species winters in the Bering Sea between St. Matthew and St. Lawrence islands, and nests on the Yukon-Kuskokwim Delta, possibly on the Seward Peninsula, across the arctic coastal plain of northern Alaska, and in arctic Russia. Spectacled eiders establish nests near shallow ponds or lakes, and are most abundant in areas with extensive wetlands. While moving between nesting and molting areas, spectacled eiders travel along the coast, sometimes up to 50 kilometers offshore. During spring migration past Barrow, they are observed migrating along leads in the sea ice. There is no designated critical habitat for spectacled eiders in Alaska.

Spectacled eiders are not known to nest in the Kotzebue area, nor on the Baldwin Peninsula. In addition, the species is not likely to migrate within Kotzebue Sound. It is likely that spectacled eiders follow leads in the Bering Sea (which are offshore from Kotzebue Sound) during spring migration to breeding grounds.

The Alaska breeding population of Steller's eiders (Polysticta stelleri) was listed as threatened on June 11,1997. The size of the Alaska breeding population is not known, but is subjectively estimated to number in the hundreds to a few thousand birds. Most of the world's population, estimated at 150,000 to 200,000 , winters in protected marine waters of the Alaska Peninsula, the coastal areas of south-central Alaska, and the eastern Aleutian Islands. Steller's eiders nest in tundra areas of the Alaskan arctic coastal plain and arctic Russia. Barrow, Alaska is the only remaining place in Alaska where Steller's eiders are known to breed regularly (although not annually), however, there are indications that breeding occurs on the Alaskan arctic coastal plain as far east as Prudhoe Bay. Post-breeding and young-of-the-year Steller's eiders may use coastal habitat in the Chukchi and Beaufort seas to feed and rest as they begin their migration back to the Bering Sea. They migrate along the coast to and from breeding grounds in spring and fall. During spring migration past Barrow, they are typically observed migrating along leads in sea ice. There is no critical habitat for Steller's eiders in Alaska.

On the Seward Peninsula, evidence of nesting by Steller's eiders has not been reported since the late 1800 's. In addition, Steller's eiders are not known to migrate within Kotzebue Sound, but instead, probably follow the offshore Bering Sea ice lead which occurs outside of the Sound.

The Service concludes that listed species are not likely to occur within the vicinity of the proposed project, and therefore, adverse effects to listed species are not likely.

We appreciate the opportunity to review this Environmental Assessment. Should you have any questions concerning the above comments, please contact Erv McIntosh at (907) 456-0444 or e-mail at ervin_mcintosh@fws.gov.

Sincerely,

Patrick J. Sousa

Field Supervisor

cc: Dave Erickson, Dames \& Moore, Anchorage 


\section{APPENDIX D}

\section{LIST OF SPECIES IN KOTZEBUE REGION}




\section{VEGETATION}

water sedge (Carex aquatalis)

Bigelow's sedge (Carex bigelowii)

russet sedge (Carex saxitalis)

short-staked sedge (Carex podocarpa)

tussock cottongrass (Eriophorium vaginatum)

bluejoint reedgrass (Calamagrostis canadensis)

Arctic bentgrass (Arctagrostis latifolia)

narrowleaf cottongrass (Eriophorium angustifolium).

woodrush (Luzula spp.)

goldenrod (Senecio spp.)

dwarf birch (Betula nana)

diamondleaf willow (Salix planifolia)

Labrador tea (Ledum decumbens)

bog blueberry (Vaccinium uliginosum)

lingonberry (Vaccinium vitis-idaea)

\section{BIRDS}

\section{Waterfowl}

Tundra Swan

Greater White-fronted Goose

Brant

Canada Goose

Green-winged Teal

Northern Pintail

Northern Shoveler

American Wigeon

Greater Scaup

Oldsquaw

Black Scoter

Shorebirds

Western Sandpiper

Whimbrel

Common Snipe

Northern Phalarope

Raptors

Northern Harrier

Rough-legged Hawks 
Golden Eagles

Merlins

Gyrfalcons

Passerines

Common and Hoary Redpolls

Wilson's Warbler

Yellow Warbler

Northern Waterthrush

Lapland Longspur

White-crowned Sparrow

Savannah Sparrow

Tree Sparrow

Fox Sparrow

\section{Other Species}

Willow Ptarmigan

Bank Swallows

Glaucous Gulls

Arctic Terns

Long-tailed and Parasitic Jaegers

Sandhill Crane

Common Raven

\section{MAMMALS}

masked and tundra shrews, snowshoe hare

tundra redbacked vole

brown and green-collared lemmings

meadow vole, Alaska vole, and tundra voles

least and short-tailed weasels

brown bear

moose

muskrat

feral reindeer

Arctic fox

red fox, coyote

wolf

muskox

caribou.

Threatened or Endangered Species

Spectacled Eider (Somateria fisheri)

Steller's Eider (Polysticta stelleri) 


\section{APPENDIX E}

NOISE AND ELECTROMAGNETIC INTERFERENCE ANALYSES 


\section{NOISE ANALYSIS}

This section describes the 148 acre wind farm site near Kotzebue Alaska specific to noise generation issues, potential noise generation, applicable noise standards, and the anticipated impact of the potential noise generation.

\section{Current Conditions}

The wind farm site is located approximately 4.5 miles south of Kotzebue Alaska, and the Kotzebue Electric Association leases the site from the Kikiktagruk Inupiat Corporation. The site currently has three AOC wind turbines in place that were installed in the spring of 1997 . A site visit was conducted during the fall of 1997, and at that time, the current condition of the wind farm site was primarily undeveloped open space with no noted significant or unusual noise generators. No noise survey data characterizing current conditions at the location of the wind farm was conducted or discovered during this investigation, however, during the site visit, the noise generated from the current wind turbines did not appear significant. Based on the site visit, it is estimated that the closest residents to the boundary of the wind farm live in the town of Kotzebue and are approximately 4.5 miles to the north. A local airport is also located between the wind farm site and the town of Kotzebue; it is approximately four miles north of the site. Also a municipal landfill is located approximately two miles northwest of the wind farm site. The local topography is nearly uniform with a general low relief. There are no significant terrain barriers in the immediate area to impede the noise that will be generated, the surface air flow, or to produce pronounced local variation in temperature or precipitation.

Indications are that there are no municipal or local noise ordinances, therefore, a review was completed of the state of Alaska's statutes for applicable noise or noise control requirements that would be applicable at the Kotzebue wind farm. Specific noise levels, for example, implementing noise area classifications, are not available in the state statutes. The requirements are more general and restrict "excessive" or "nuisance" noise and include requirements for not having an adverse impact in the area.

\section{Potential Noise Generation}

Noise generation as a result of this project is expected to consist of construction and maintenance of the wind farm and any associated facilities. In addition, the daily operation of the wind farm turbines is expected to generate the worst case and a long-term noise generation.

Construction and development of the facilities is expected to generate noise primarily from internal combustion engines used to power the construction equipment and conduct operations. Specific noise generation and characterization depends on the type of equipment used, the amount of equipment operating simultaneously, and hours of operation. It is anticipated that typical construction equipment will be used and that the hours of operation will occur only during normal working hours. As described in section 2.5, it is anticipated that the construction period will be a relatively short time period. Because of the noise standards that construction equipment manufactures are required to adhere to, it is not anticipated that excessive or unusual 
noise generation will result from the construction operations. In addition, assuming the construction operations occur only during normal working hours it is anticipated that the noise generation will not significantly impact potential nearby receptors.

Wind farm operations are expected to occur 365 days per year, 24 hours per day and include periodic maintenance operations. The traffic associated with these operations is not expected to significantly contribute to the total noise characteristics of the respective area. The primary noise generator is expected to be the wind turbines. A sound survey was not conducted during the site visit to analyze the noise generated by the existing wind turbines, however, vender noise data is available. Using estimates and assumptions that are reasonably conservative, noise levels of the AOC 15/50 wind turbine were estimated to be $104 \mathrm{~dB}(\mathrm{~A})$ at the hub with an . 18 mile per hour wind (NREL 1997). This estimation is consistent with the Acoustics Measurement of Noise Emission From Wind Turbines (Expert Group Study 1994). Based on other vender data and information, this noise level appears to be on the high side for modern wind turbines, but will be used as a conservative basis for the purposes of this noise evaluation. Assuming a relatively high noise level as a basis will help ensure a conservative review of the potential noise impacts.

The primary assumptions used in reviewing the potential noise impacts are:

- $104 \mathrm{~dB}(\mathrm{~A})$ noise level at the hub of each wind turbine

- The wind farm will contain a maximum of 20 wind turbines

- The hub height of each wind turbine will be a minimum of 24 meters

- There are no other significant noise generators in the vicinity of the wind farm

- A municipal landfill is located approximately two miles northwest of the site

- An airport is located approximately four miles north of the site

- The nearest residential receptor is approximately 4.5 miles north in the town of Kotzebue.

The total noise generated by up to 20 wind turbines is estimated based on the relationship among sound power, sound intensity, sound power level, and the addition of harmonic waves. Using these relationships as described in the Noise Control: Handbook of Principles and Practices (Lipscomb, Taylor, 1978), it is conservatively estimated that the maximum noise level is approximately $114 \mathrm{~dB}(\mathrm{~A})$ assuming 10 or more wind turbines. Assuming a worse case configuration of all wind turbines being essentially at the same location the additivity of the noise from each wind turbine continues at a nonlinear scale until the eleventh wind turbine is added at which point the increase is insignificant and may be neglected. Therefore the maximum noise generated is with a configuration of 10 co-located wind turbines. Assuming the wind turbines are on 24 meter towers the noise level at the ground can be estimated by using the following equation (Lipscomb, Taylor, 1978): 


$$
\text { NoiseL }=\text { SNoiseL }-10 \times \log \left(4 \times \pi \times R^{2}\right)
$$

where:

NoiseL $=$ Noise level at distance $R$ in $\mathrm{dB}(\mathrm{A})$

SNoiseL = the source noise level in $\mathrm{dB}(\mathrm{A})(104 \mathrm{~dB}(\mathrm{~A}))$

$\mathrm{R}=$ the distance from the source in meters (24)

Using this relationship it is estimated that the noise level at the ground level is approximately 75 $\mathrm{dB}(\mathrm{A})$ assuming 10 or more wind turbines simultaneously operating. This noise level is below the federal requirements for occupational hearing conservation programs and in addition will decrease as the distance from the noise source increases. Using the same relationship as described in the above equation, noise levels were estimated for distances further away from the wind farm and are shown in the table below.

\begin{tabular}{cc}
\hline Noise Level (in dB(A)) & At Distance (in meters) \\
\hline 75 & 24 \\
63 & 100 \\
49 & 500 \\
43 & 1000 \\
37 & 2000 \\
33 & 3219 (landfill) \\
29 & 5000 \\
27 & 6437 (airport) \\
26 & 7242 (Kotzebue) \\
\hline
\end{tabular}

To put these noise level estimates into perspective; normal conversation at approximately one meter has a sound pressure of approximately $60 \mathrm{~dB}$; a quiet office has a sound pressure of approximately $50 \mathrm{~dB}$ and is considered quiet; and finally a soft whisper at five meters is approximately $30 \mathrm{~dB}$ and is considered very quiet (Lipscomb, Taylor, 1978). Based on the estimated noise levels it is not anticipated that any significant noise impact will result from the wind farm. Directly at the wind farm, workers or maintenance personnel will not likely be required to use hearing protection and at the landfill, the airport, or at the town of Kotzebue the noise will be negligible. 


\section{REFERENCES:}

(Lipscomb, Taylor, 1978), Noise Control Handbook of Principles and Practices, Van Nostrand Reinhold Environmental Engineering Series, 1978.

(Expert Group Study 1994), Expert Group Study on Recommended Proctices For Wind Turbine Testing And Evaluation, 4. Acoustics Measurement of Noise Emission From Wind Turbines, 3. Edition 1994.

(NREL 1997), Communication with NREL Wind Energy Program, December 9, 1997. 


\section{ELECTROMAGNETIC INTERFERENCE ANALYSIS}

The purpose of this section is to describe potential electromagnetic interference (EMI) as it is applicable to the proposed wind farm site located near Kotzebue Alaska and the potential effect on radio services. The wind farm site is located approximately 4.5 miles south of Kotzebue Alaska, and the Kotzebue Electric Association leases the site from the Kikiktagruk Inupiat Corporation. The site currently has three AOC wind turbines in place that were installed in the spring of 1997. A site visit was conducted during the fall of 1997, and at that time, the current condition of the wind farm site was primarily undeveloped open space. A local airport is located between the wind farm site and the town of Kotzebue; it is approximately four miles north of the site. A local AM radio station (KOTZ) is located in the town of Kotzebue and operates at the frequency of 700 kilohertz. The KOTZ antenna is located approximately 1000 feet to the west of the wind farm site. Also the abandoned U.S. Air Force White Alice Communications station is located less than one mile to the west of the site. The local topography is nearly uniform with a general low relief. There are no significant terrain barriers in the immediate area, or pronounced local variation in temperature or precipitation.

The potential EMI effects of wind turbines on radio services involve multiple parameters including: the type of wind turbine, whether it is on a vertical or horizontal axis, the diameter and number of blades, the shape of the blades and properties of their materials, and the height of the support tower. Also applicable for wind turbines with blades made of dielectric materials, or materials which are an electrical insulator, are the shape and location of any metal parts such as lightning conductors or spars. The electromagnetic scattering properties of a wind turbine is a complex condition and involves three dimensional vector fields incident upon a time varying structure and requires many parameters for its description. The analytical descriptions use electromagnetic analysis techniques to categorize the EMI situation into three classes dependent upon their dimensions in terms of a wavelength, (Expert Group Study 1986).

The vulnerability of various radio services to EMI effects is dependent upon some primary parameters of the radio service. The primary parameters are: spatial positions of the transmitter and receiver with respect to the wind turbine; carrier frequency; polarization of the signal; modulation type and frequency; time constants of the automatic gain or other controls; and the symbol rate of digital systems, (Expert Group Study 1986).

A semi-quantitative analysis has been performed and is documented in a paper titled, "Some Comments on Possible Electromagnetic Interference Attributable to Wind Machines," (Nix, 1998) This paper specifically evaluates the EMI situation at Kotzebue against the background of the existing technical literature on this subject. The conclusions are specific to AM broadcast reception, FM/TV broadcasting, aircraft navigation, cellular telephones, and the Air Force Radar Installation. It is expected that very little reradiation and essentially no interference will occur with the KOTZ radio broadcast because the wind turbines/wind machines near the radio antenna present only about $5 \%$ of a wavelength in any dimension. Currently there are no conventional TV or FM broadcasting stations in the 
Kotzebue area and therefore interference is not an issue. In addition, receiving dish antennas for satellite reception have beam widths of only a few degrees and they are oriented to a specific satellite(s), therefore, wind farm interference is not expected. The airport is located approximately four miles north of the wind farm site and has not observed any wind machine related interference with their aircraft navigation systems. In addition, a report by D.L. Sengupta and T.B.A. Senior indicates that no significant degradation of VHF Omnidirectional Ranging (VOR) systems will occur assuming wind turbines are sited according to FAA guidelines, (Sengupta, Senior 1977). There is currently no cellular service in the Kotzebue area and therefore interference is not an issue. The abandoned U.S. Air Force White Alice Communications station is no longer in operation, therefore interference is also not considered an issue. In addition, radar antenna systems typically have very narrow beams in order to measure directions accurately, therefore interference is not anticipated even if the systems were operational.

Based on the reviewed information, and assuming the electromagnetic related services do not change in the Kotzebue area, it is not anticipated that the planned wind farm will cause any noticeable EMI issues.

\section{REFERENCES}

(Sengupta, Senior 1977), Sengupta, D.L., Senior, T.B.A., "Electromagnetic Interference by Wind Turbine Generators. Final Report," ERA-04-018651; EDB-78-002112; Michigan Univ., Ann Arbor MI, February 1977.

Nix, Gerald. 1998. National Renewable Energy Laboratory . Memorandum to E. Lurier, Dames \& Moore. "Some Comments on Possible Electromagnetic Interference Attributable to Wind Machines"

(Expert Group Study 1986), Expert Group Study on Recommended Practices For Wind Turbine Testing And Evaluation, 5. Electromagnetic Interference, Issue 1, February 1986. 